\title{
Convento di San Francesco a Folloni: the function of a Medieval Franciscan Friary seen through the burials
}

\author{
Marielva Torino ${ }^{1}$, Jesper L Boldsen², Peter Tarp², Kaare Lund Rasmussen ${ }^{3 *}$, Lilian Skytte ${ }^{3}$, Lisbeth Nielsen ${ }^{3}$, \\ Simone Schiavone ${ }^{4}$, Filippo Terrasi ${ }^{5,6,7}$, Isabella Passariello ${ }^{5,6}$, Paola Ricci $^{8}$ and Carmine Lubritto ${ }^{8}$
}

\begin{abstract}
Background: The Franciscan Friary in Montella near Avellino in Southern Italy is of special interest because according to historical sources it was founded by St. Francis himself in AD 1221-1222. Human remains of several hundred individuals interred in the cloister walk have been unearthed during two excavation campaigns conducted in 2007-2008 and 2010. The environs of the friary have remained rural since the foundation preventing much modern contamination. The state of preservation of the skeletons is fair to good making a suite of analyses worthwhile.

Results: The skeletons have been examined anthropologically and tissue samples have been subjected to radiocarbon dating, stable isotope measurements and trace element analyses by Inductively Coupled Plasma Mass Spectrometry and Cold Vapour Atomic Absorption Spectrometry.

Conclusions: The radiocarbon dates are consistent with the historical sources and show that the cemetery in the cloister walk has been in uninterrupted use from the foundation of the friary in AD 1221-1222 and until the cemetery went out of use in AD 1524. The anthropological investigations show that the individuals interred at the friary would have been shorter than other Italians from the same time, and it seems that tuberculosis was more prevalent than leprosy. Isotopic measurements show a mixed agricultural and pastoral diet and none of the individuals were consuming marine protein. Based on the trace element analysis it seems that the people resided mainly at two distinct geographical areas, one of which was Montella. One individual stands out from the rest, because he was born and raised at some third geographical location distinct from Montella and because he sports the second oldest radiocarbon date of AD 1050-1249 (two sigma calibrated range). This date is consistent with the first generation of the founders of the friary-perhaps one of St. Francis' fellow travellers from Assisi.
\end{abstract}

Keywords: Franciscan friary, Montella, Osteology, Trace elements, Radiocarbon, Stable isotopes

\section{Background}

According to tradition the Franciscan Friary at Folloni near Montella in Southern Italy (Fig. 1) was founded by St. Francis of Assisi himself. St. Francis arrived together with a fellow friar at Montella in the winter of AD 12211222. They were rejected at the city gate on the suspicion of suffering from leprosy. After walking a short distance, about a kilometre, to the Folloni forest they settled for

\footnotetext{
*Correspondence: klr@sdu.dk

${ }^{3}$ Department of Physics, Chemistry and Pharmacy, University of Southern

Denmark, Campusvej 55, 5230 Odense M, Denmark

Full list of author information is available at the end of the article
}

the night under a tree where they were shielded from the snow by godly intervention. On this site, where St. Francis and his fellow traveller slept, the friary was subsequently founded [1-5].

The purpose of this paper is to investigate the relationship between the friary and the surrounding society and in this way gain knowledge about the growth of a monastic settlement over 300 years. The monastic institutions formed the background for the social and political order in Europe throughout the medieval period. In order to fulfil this purpose, three different types of analyses have been carried out: an archaeological analysis of the

\section{Chemistry Central}

(c) 2015 Torino et al. This article is distributed under the terms of the Creative Commons Attribution 4.0 International License (http://creativecommons.org/licenses/by/4.0/), which permits unrestricted use, distribution, and reproduction in any medium, provided you give appropriate credit to the original author(s) and the source, provide a link to the Creative Commons license, and indicate if changes were made. The Creative Commons Public Domain Dedication waiver (http://creativecommons.org/ publicdomain/zero/1.0/) applies to the data made available in this article, unless otherwise stated. 


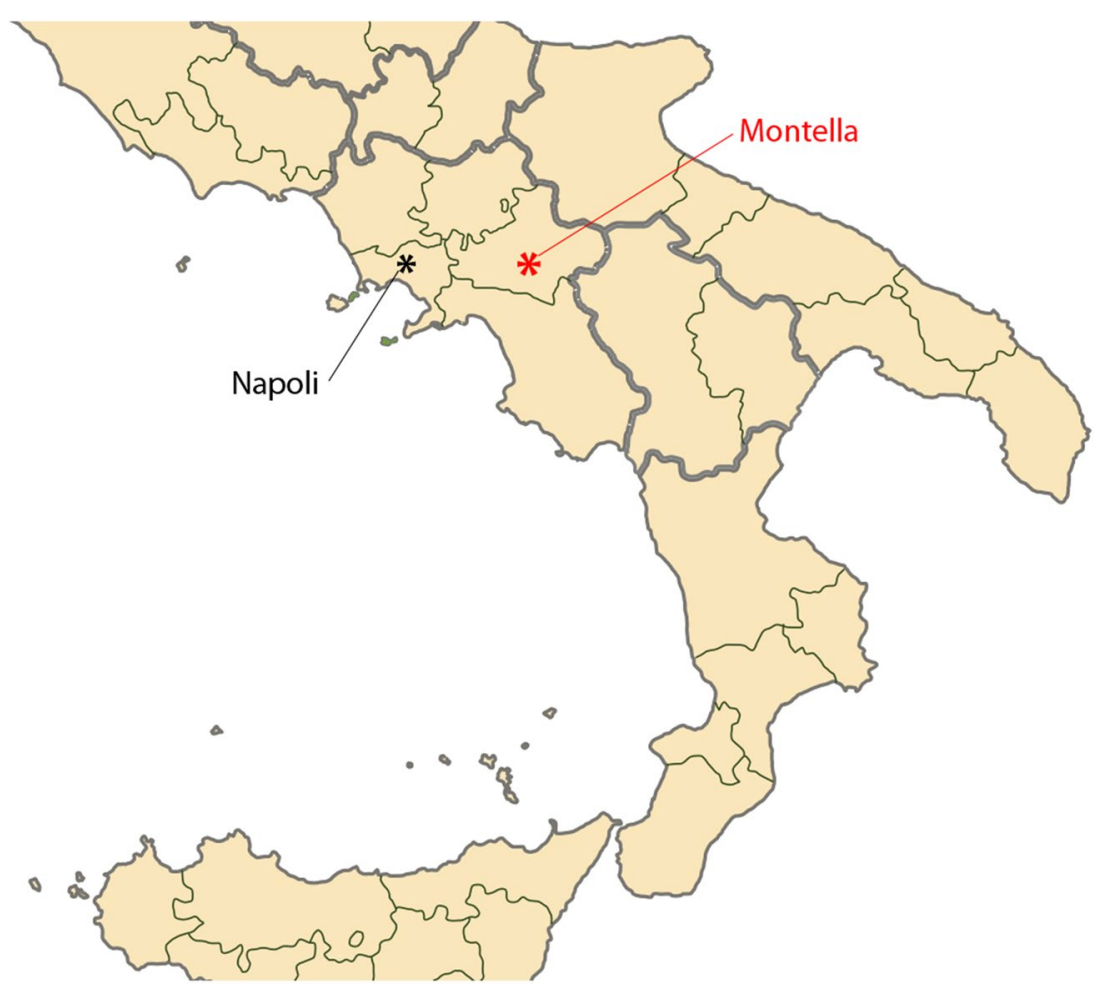

Fig. 1 Location map, the red star indicates the position of Montella near Avellino in Southern Italy.

building and burial history of the site based on observations from two excavations; an osteological analysis of the skeletons interred in the friary; and chemical analyses including ${ }^{14} \mathrm{C}$ dating, stable isotopes and trace elements of individual skeletons to describe the life and migration history of the people interred in the friary.

\section{Building history and excavations}

After the founding of the friary in the third decade of the 13th Century, a church and an extensive building complex were erected. Five hundred years later, in 1732, the friary was demolished by an earthquake, and today virtually nothing is left above-ground of the first building complex. A new friary was re-erected on the site later in the 18th Century, but only partly in accord with the original layout of the complex. The outline of the original and the re-erected building complex is shown in Fig. 2.

The cloister walk was the only compartment that was left on its original footprint from the old complex. The church was rotated $90^{\circ}$ around the altar which today is still at the same position as it was in the 13th Century church, and it is still elevated ca. $180 \mathrm{~cm}$ over the church floor. The front entrance of the friary was replaced by the installation with two rows of columns (antichiostro). The southern corridor of the new cloister walk is only in contact with the old cloister walk over $2.5 \mathrm{~m}$. This small overlap can be seen in the drawing of the layout of the buildings erected in 1740-1741 made immediately before the repair work took place ([4, 5]; Fig. 2).

In the fall of 2007 a small exploratory excavation was carried out aimed at assessing the archaeological potential of the area. The main excavation lasted for a year and covered most of the cloister walk with a total area of approximately $160 \mathrm{~m}^{2}$. Another excavation followed in August 2010 where a field of the southern corridor of the cloister walk (an area of $18.5 \times 2.5 \mathrm{~m}$ ) was excavated. The modes of investigation of the two excavations were different. The 2007-2008 excavation was scheduled as an educational excavation with 12 archaeology students lead by M. Torino. The 2010 excavation was led by S. Schiavone and was conducted for the local Archaeological Service in order to give way for repaving work.

The two excavations in 2007-2008 and 2010 resulted in retrieving the bones from 44 more or less intact graves (Fig. 3). Later osteological analyses proved that remains of many more individuals were indeed present as comingled bones.

The first excavation revealed 23 graves in two corridors, A and B (see Fig. 2), of the four corridors of the cloister walk. Seen from an archaeological point of view the graves seem to belong to three different time periods. One of the oldest burials (T-4 USD230) was oriented 
Fig. 2 Synthesis of the building archaeological observations of the Franciscan Friary at Folloni, Montella. The buildings of the original friary are depicted in red; the re-constructed buildings after the 1732 earthquake are depicted in grey.

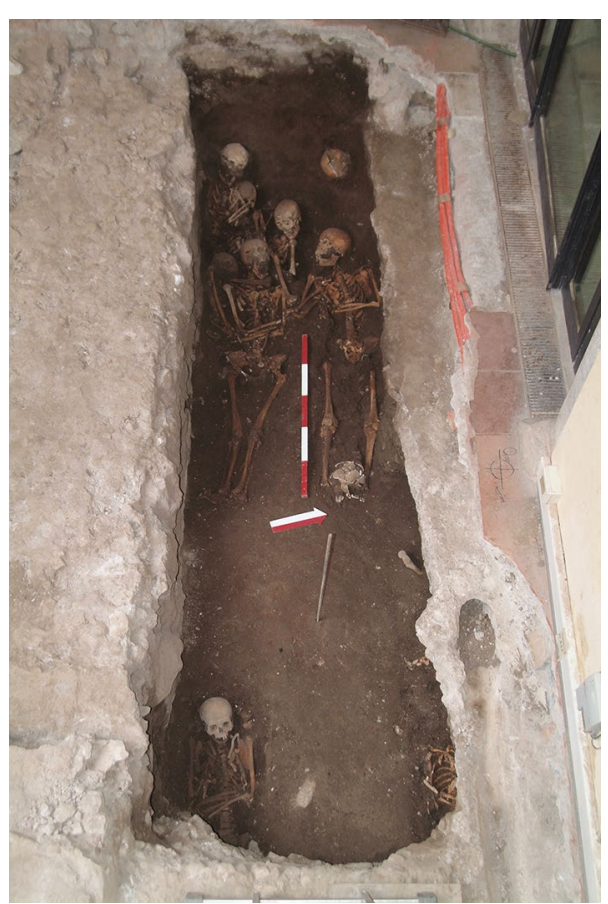

Fig. 3 Photo of one of two rectangular grave sites with multiple burials (14th century). east-west and situated in the cloister garden. This grave represents the earliest element of the development of the cemetery. Five other tombs from this period have been identified (T-20 USD295, T-18 USD350, T-1 USD-210, T-14 USD274, and T-13 USD-265).

Three burials, including a double grave, were destroyed by the re-construction of the friary, with the building of the nave of the church on the south side. The building activity at this place probably took place by the end of the 13th Century and the first quarter of the 14th. The remaining burials respect the orientation of the two orthogonal arms A and B, and can be referred to the last period of the funerary activity lasting apparently without interruption until 1524. Archival documents from 1524 indicate the existence of a wrought of mortar which was identified in its full extent in the excavation of the north corridor.

The 2010 excavation revealed a greater number of skeletons, probably due to the more prominent position near the entrance of the church; the area can be identified as the paradisus. There are 38 primary burials and ca. 12 burials which have been cut by later activity in the soil. The observations of the second excavation are consistent with the burials unearthed in the first excavation 
and can also be interpreted as belonging to three periods. Nine graves can be assigned to the early period, including 3 from a masonic tomb which includes a double grave where the bodies were positioned on top of one another (USD 397 and 408).

In the late period of use two separate areas of graves were found in rectangular shaped areas $(3.86 \times 1.65$ and $4.18 \times 1.40 \mathrm{~m}$, respectively), each with ca. 11 graves and two collective tombs buried in two trenches $(3.92 \times 1.43 \mathrm{~m})$ separated by a strip of sterile soil between them. The burial pattern suggests that these graves could have been almost contemporary.

\section{Osteological methods}

Osteologically, the Montella skeletons were examined in two rounds. The first round was aimed at collecting general data on size, sex, age and diseases. These data were collected to facilitate a reconstruction of the characteristics of the population at the site while it was still alive. The second round of examinations was aimed at collecting in-depth information about the life (and death) of selected individuals in order to get a better understanding of single individuals.

\section{Sex}

Sex was primarily estimated from traditional methods which include differences on the pelvis and on the skull [6]. Furthermore measurements of the femoral head [7], the humeral head and the humeral epicondyle [8] were used to assess the sex. It must be stressed that osteologists assess sex, viz. the biological aspect of the difference between men and women whereas archaeologists tend to assess gender, the cultural aspect of the difference between men and women. Primarily, sex was recorded on a 1-7 scale. The meaning of these scores are (1) definitely male (M); (2) probably male (M?); (3) possibly male (?M); (4) undetermined (?- children end up in this category); (5) possibly female (?F); (6) probably female (F?); and (7) definitely female (F). In the further analyses, codes 1 and 2 are treated as males and codes 6 and 7 as females.

\section{Age at death}

Age at death was estimated using the so called 'experience-based method' [9]. The method is based on primarily so far undescribed anatomical traits. The skeletal characters traditionally used for age estimation like closure of the cranial sutures, changes on the pubic symphysis and the auricular surface, and transformation of the sternal end of the 4th rib provide much less accurate age information and the statistical approach used to generate age standards from these characters are, with the exception of Transition Analysis [10], seriously biased [11]. The experience-based method is based on data from all parts of the skeleton, as it utilizes virtually every bone in the body-most notably the vertebrae, proximal femur and the ribs.

\section{Femoral length}

The femoral length was measured on all skeletons with fused epiphyses. This was the only anthropometric measurement included in the general description of the population. It would, of course, be valuable to have information about stature in the once living population but due to burial custom and conditions of preservation it was not possible to measure the length of the buried bodies in accord with the method described by Boldsen [12].

\section{Skeletal trauma}

Skeletal trauma are coded independently of them being perimortal (fresh) or healed. Analyses of trauma were not a main purpose of the research into the Montella skeletons. So in the general examination traumatic lesions were only recorded to one of the bodily regions: Head, arms, legs and the rest.

\section{Joint degeneration}

The four largest joints in the body-shoulder, hip, knee and ankle-were scored for changes in the joint. Minor changes occur in virtually everybody beyond the age of 30 and they were probably not associated with any discomfort. As a consequence of this only major joint changes were recorded. Joints with either eburnation on the surface of the joint or extensive lipping/ostephythosis along the rim of the joint were classified as positive for joint degeneration. Extensive lipping or ostephythosis is defined as sharp bony outgrowth along the edge of the joint being at least one $\mathrm{cm}$ long and extending at least one mm over the surface of the joint.

\section{Tuberculosis}

Tuberculosis can leave its characteristic marks virtually all over the body. In the present study, however, such lesions were only recorded in the spine. The nutrient foramina in the vertebrae can enlarge to $3 \mathrm{~mm}$ with a funnel shaped opening due to tuberculosis. Individuals were considered unaffected if they had normal sized and shaped nutrient foramina. Where the cranial and/or the caudal surfaces of the vertebral bodies show invasive porous destruction and depressions this is considered to indicate tuberculosis; this is also the case for Pott's disease, and wedge shaped vertebras that can be seen as advanced cases of the destruction just described [13]. The spinal lesions are recorded separately for the thoracic and the lumbar region of the spine. 


\section{Leprosy}

For the registration for leprosy seven anatomical traits are examined. These traits are: (1) the edge of the nasal aperture that can be 'normal' sharp or rounded and affected. (2) The anterior nasal spine can be pointed (unaffected) or degenerated or rounded (affected). (3) The alveolar process of the pre-maxilla can be normal and unaffected or can be retreated (affected). (4) The palate can appear with no or little porosity (unaffected) or with densely pitted or perforated palate (affected). The fibula can appear with a smooth surface (unaffected) or fibula with subperiostal exostoses (affected) (5) or a swollen fibula (6). (7) The fifth metatarsal bone can appear with a normal surface (unaffected) or with periostitis or exostoses or shortened and deformed [14].

\section{Statistical methods}

The statistical analyses of the anthropological observations were carried out using SPSS (v. 21.0). For the most parts standard statistical methods like cross-table analysis, un-paired $t$ test and Kaplan-Meier survival analysis using the Mantel-Cox log-rank test applied to test for effects of covariates like sex or disease status.

The diagnostic and epidemiological analysis of leprosy is statistically far more developed than the analysis of any other disease in the past. Here we have used the $\lambda$-method first for estimating the sample frequency of leprosy. This statistic could be named the point prevalence of leprosy at death in the population buried at the Montella friary. Once this frequency is estimated, individual skeleton disease status can be assessed-of course as probability statements. This approach has been developed and described previously [15-17].

\section{Chemical and physical methods}

\section{Sampling of the bone for trace element analyses}

The sampling of the bones took place at the premises of the friary 2 years after the excavations. Great care was taken to avoid contamination during the field sampling. Laboratory coats, plastic gloves, hairnets and facemasks were used throughout the sampling process. A large sheet of white paper was covered by two layers of Alfoil on top of which the bone was placed. The drill used was a conical drill bit mounted on a Dremel MultiPro ${ }^{\circledR}$ electric drill. The drill bit and the other utensils used for handling the bone samples were rinsed in MilliQ ${ }^{\circledR}$ water and heated to dryness in an ethanol flame before drilling in order to decontaminate the utensils of any $\mathrm{Hg}$ possibly present. A small area of bone surface was drilled off down to ca. $1 \mathrm{~mm}$ and discarded together with the gloves and the top layer of Al-foil. The utensils were cleaned again in MilliQ water and heated in the ethanol flame. A new sheet of Al-foil was added and new gloves were used. The bone sample was drilled in the decontaminated area without touching the remaining bone surface surrounding the decontaminated area. Approximately $50 \mathrm{mg}$ granulated bone was transferred to a pre-cleaned glass vial and sealed.

\section{ICP-MS analysis}

The trace elements were analysed by ICP-MS and CVAAS at the CHART laboratory (Cultural Heritage and Archaeometric Research Team at SDU). The sample weight used for ICP-MS analysis was approximately $20 \mathrm{mg}$ [18]. The bone samples were handled by a stainless steel spoon, which was rinsed in MilliQ water and heated in an ethanol flame between each sample. After weighing the sample was transferred to a $50 \mathrm{~mL}$ polypropylene centrifuge tube. To dissolve the sample, $2 \mathrm{~mL}$ of conc. $69 \%$ ICP-MS grade $\mathrm{HNO}_{3}$ and $1 \mathrm{~mL}$ of conc. 30\% ICPMS grade $\mathrm{H}_{2} \mathrm{O}_{2}$ were added to the tube. Subsequently the lid was loosely fitted on tube and the tube was placed on a shaking table for no less than $3 \mathrm{~h}$. The amount of $\mathrm{H}_{2} \mathrm{O}_{2}$ consumed in the dissolution process depends on the amount of organic compounds present in the sample, which varied from sample to sample. To remove the surplus $\mathrm{H}_{2} \mathrm{O}_{2}$ and to dissolve any possibly remaining solids, $335 \mu \mathrm{L}$ of conc. $37 \%$ ICP-MS grade $\mathrm{HCl}$ were added, after which the tube with the lid loosely fitted was placed on the shaking table overnight.

The samples were diluted quantitatively to $10 \mathrm{~mL}$ with MilliQ water and then filtered through a $0.45 \mu \mathrm{m}$ PVDF Q-Max ${ }^{\circledR}$ RR Syringe filter into a $15 \mathrm{~mL}$ polypropylene centrifuge tube. Further quantitative dilution was done in the $15 \mathrm{~mL}$ tubes according to the concentrations of specific sample, for normal samples using $3 \mathrm{~mL}$ sample solution and $9 \mathrm{~mL}$ MilliQ water. This way the diluted sample acquired an acid concentration of approximately $1 \%$, which is well suited for analysis. The remaining filtrate was stored in the sealed tubes in a refrigerator at $5^{\circ} \mathrm{C}$ for CV-AAS analysis for $\mathrm{Hg}$.

The ICP-MS analyses were carried out using a Bruker ICP-MS 820 equipped with a frequency matching RFgenerator and a Collision Reaction Interface (CRI), the latter operated with either helium or hydrogen. The samples were introduced into the system using a Bruker SPS3 autosampler and an OneFast flow injection inlet system. The basic parameters were as follows: radiofrequency power $1.40 \mathrm{~kW}$; plasma gas flow rate $15.50 \mathrm{~L} \mathrm{~min}^{-1}$; auxiliary gas flow rate $1.65 \mathrm{~L} \mathrm{~min}^{-1}$; sheath gas flow rate $0.12 \mathrm{~L} \mathrm{~min}^{-1}$; nebulizer gas flow rate $1.00 \mathrm{~L} \mathrm{~min}^{-1}$. The following isotopes were measured without skimmer gas: Mg24, Al27, Ca44, Mn55, Zn66, Sr88, Ba137 and a combination of $\mathrm{Pb}$ isotopes (Pb206, Pb207 and $\mathrm{Pb} 208)$. The CRI Reaction System was activated for $\mathrm{Cu}$ and Fe because of interferences with polyatomic species produced by a 
combination of isotopes from the argon plasma, reagents and the bone matrix. Fe56 was measured with hydrogen as skimmer gas and $\mathrm{Cu} 63$ with helium as skimmer gas. A mixture of Sc45, Y89 and Tb159 was used as internal standard and added continuously to all samples. The dwell time on each peak was between 5 and 20 ms. Five replicate analyses were made of each of the dissolved bone samples and each replicate consisted of 30 mass scans. ICP multi-element standard solution XXI for MS (Merck) were prepared in $1 \% \mathrm{HNO}_{3}$ at 6 different concentrations $\left(0.1,1,10,20,100\right.$ and $\left.200 \mu \mathrm{g} \mathrm{L}^{-1}\right)$, but for each element only 3 of the standards were selected to fit the appropriate concentration range in the samples. For the main element $\mathrm{Ca}$ three standards (Fluka TraceCert ${ }^{\circledR}$ ICP Standard) of concentrations 10, 20 and $25 \mathrm{wt} \%$ were used. Elements showing higher than expected concentrations had their count rates attenuated automatically in the detector. A sample of water and a blank sample consisting of $1 \% \mathrm{HNO}_{3}$ were run before the standard blank to ensure that no pollution was lingering in the system at start up. A blank sample was analysed between each bone sample in order to rinse the system and avoid any memory effects. Each working day an in-house standard sample made of a homogenized medieval bone was analysed along with the samples in order to monitor the overall performance. Together with the samples was run an international standard sample, NIST SRM-1486, a modern bone sample. For these modern samples more $\mathrm{H}_{2} \mathrm{O}_{2}$ had to be added.

\section{Mercury analysis}

Mercury was analysed by CV-AAS. After weighing, ca. $20 \mathrm{mg}$ of sample was transferred to a centrifuge tube. The bone powder was dissolved in $2 \mathrm{~mL}$ conc. $69 \%$ ICP-MS grade $\mathrm{HNO}_{3}$ and $1 \mathrm{~mL}$ conc. $30 \%$ ICP-MS grade $\mathrm{H}_{2} \mathrm{O}_{2}$ [19]. Afterwards the tubes were placed on a shaking table for 3-4 h; following which $0.335 \mathrm{~mL}$ concentrated $37 \%$ ICP-MS grade $\mathrm{HCl}$ was added in order to remove any superfluous $\mathrm{H}_{2} \mathrm{O}_{2}$. The samples were left overnight on the shaking table with the caps loosely fitted. The solution was diluted with $16 \mathrm{~mL}$ of MilliQ water. $1 \mathrm{~mL}$ of $5 \mathrm{ppm}$ $\mathrm{KMnO}_{4}$ was added in order to make sure that the $\mathrm{Hg}$ was kept in the oxidized state. The samples were placed on the shaking table for at least $2 \mathrm{~h}$ to allow the reactions to run to completion. Five standard solutions in the concentration range 25-200 ppb were prepared using a PerkingElmerPure mercury nitrate standard solution in diluted $\mathrm{HNO}_{3}$ (1.5\%). The $\mathrm{Hg}$ was measured by cold vapour atomic absorption spectroscopy on a Flow Injection Mercury System 400 manufactured by PerkinElmer. The $\mathrm{Hg}$ was released as vapour in the FIMS-400 by adding $\mathrm{NaBH}_{4}(0.2 \%)$ in $0.05 \% \mathrm{NaOH}$. The analyses were then run in triplicate in an alternating sequence with a blank sample between each of the bone samples. A solution of the in-house medieval bone standard was measured each day in order to check performance.

\section{Radiocarbon dating}

Fifty samples were radiocarbon dated at the CIRCE laboratory (Centre for Isotopic Research for Cultural and Environmental heritage). The commonly analysed fraction for bone radiocarbon dating is the collagen. In order to remove any contaminants introduced after death and to extract the collagen fraction, all analysed bone samples were treated using a protocol known as Gelatinization. This process is effective in removing contaminants on samples younger than 20,000 years [20-22].

The bone samples were crushed and treated with the AAA protocol, a series of acid and basic attacks, in order to remove carbonates and humic acids and to extract the collagen. Then the GEL fraction was obtained by heating the collagen to $70^{\circ} \mathrm{C}$ in a solution with $\mathrm{pH} 3$ for $20 \mathrm{~h}$ [23]. Finally the gel was freeze-dried and used for the successive combustion and graphitization processes [24, 25]. The obtained graphite was measured for the ${ }^{14} \mathrm{C} /{ }^{12} \mathrm{C}$ isotopic ratio using a NEC $3 \mathrm{MV}$ accelerator mass spectrometer [26]. The measurements were expressed as ${ }^{14} \mathrm{C}$-ages calculated according to Stuiver and Polach [27] and calibrated by using the OxCal v4.2.3 program [28] and the IntCal13 calibration curve [29].

\section{Paleo diet analyses}

Stable isotopes analysis of human collagen has proven to be a reliable method for reconstructing the diet of ancient populations [30-32]. Isotope composition, i.e. stable isotope ratios of carbon $(\mathrm{C})$ and nitrogen $(\mathrm{N})$, expressed in term of delta notation $\left(\delta^{13} \mathrm{C}\right.$ and $\left.\delta^{15} \mathrm{~N}\right)$, in the body tissues reflect that of the consumed food. The principles, allowing the reconstruction of human paleo diet from stable isotope analysis are well known: bone collagen, with its turnover rate of around $3 \%$ per year (for a typical male adult), expresses a representative record of an individual's diet, albeit between diet and bone collagen there is an offset of $5 \%$ in $\delta^{13} \mathrm{C}$ and $3 \%$ in $\delta^{15} \mathrm{~N}$. Isotopic signatures at the origin of a trophic chain characterize the chain itself (for example, marine or terrestrial). The increase of $\delta^{13} \mathrm{C}$ in human diet arises mainly as a result of the consumption of two types of ${ }^{13} \mathrm{C}$-enriched foods. Firstly, marine foods are characterized by $\delta^{13} \mathrm{C}$ values $\sim 7 \%$ higher than terrestrial foods. Secondly, different photosynthetic pathways fractionate carbon isotopes differentially; therefore $\mathrm{C} 4$ plants have $\delta^{13} \mathrm{C}$ values of their tissues about $17 \%$ higher than the corresponding components of $\mathrm{C} 3$ plants. Using $\mathrm{C}$ isotopes alone these two ${ }^{13} \mathrm{C}$-enriched sources (C4 plants and marine foods) cannot be distinguished from one another, or reveal the 
consumption of animal derived protein. Therefore, $\delta^{15} \mathrm{~N}$ in collagen is necessary auxiliary information. Much of the variation in $\delta^{15} \mathrm{~N}$ largely arises as a result of the trophic level effect: carnivores have higher $\delta{ }^{15} \mathrm{~N}$ values than herbivores, whom they feed on, and the greater is the number of trophic levels between a prey and its predator, the larger is the difference in their $\delta^{15} \mathrm{~N}$. The number of trophic levels in the marine and aquatic realms is greater than on land. Therefore the consumption of small fish is unlikely to produce high $\delta^{15} \mathrm{~N}$ values because they are low trophic level feeders. Moreover, the highest $\delta^{15} \mathrm{~N}$ values in humans are observed where marine or aquatic foods are important in the diet. Humans that consume only terrestrial protein sources may have collagen $\delta{ }^{13} \mathrm{C}$ values of approximately $-20 \%$, and $\delta^{15} \mathrm{~N}$ values ranging from 5 to $12 \%$, while humans that consume marine food have collagen $\delta^{13} \mathrm{C}$ values close to $-12 \%$ and $\delta^{15} \mathrm{~N}$ values between 12 and $22 \%$. On the other hand, humans who consume a mixture of terrestrial animal and marine protein would have isotopic values somewhere between the above end points. This general schematization, useful to the understanding of the measurement results, is not universally valid; it could differ from site to site due to local contamination causing systematic variation of the whole food chain. Therefore, the site must be characterized by measuring faunal remains (e.g. sheep, cattle) for reference purposes since their role in the trophic levels is well known and constant.

The stable isotopes were measured at the SUN IRMS Laboratory at CIRCE (Centre for Isotopic Research for Cultural and Environmental heritage). As in the case of radiocarbon dating, the samples for the paleo diet analyses were processed to isolate the collagen. This was done using a modified procedure of the method described by Longin [20]. The bone surface was abraded to remove any contaminants and the sample was pulverized. Each sample was placed in a polypropylene test tube and demineralised in a sequence of acid treatments with $0.6 \mathrm{M} \mathrm{HCl}$ at room temperature $\left(20-25^{\circ} \mathrm{C}\right)$, interrupted by a 30 -min alkaline treatment with $0.1 \mathrm{M} \mathrm{NaOH}$. Several rinses with de-ionized water were carried out after each step, until neutrality was achieved, before drying the samples in an oven. Finally the gelatinization protocol [23] was applied. In order to test the quality of the collagen, $\mathrm{C}$ and $\mathrm{N}$ fractions of dry collagen were measured by an elemental analyser (CN Flash EA 1112, Thermo Scientific, Bremen) and expressed in \% C and \% N. Samples were retained for isotope analyses provided the extracted collagen achieved a yield higher than $1 \%$ and an atomic C:N ratio between 2.9 and $3.6[33-35] . \delta^{15} \mathrm{~N}$ and $\delta^{13} \mathrm{C}$ were measured concurrently in continuous flow mode on a Thermo Scientific Delta Plus mass spectrometer.

\section{Results and discussion}

\section{Age at death, sex and mortality}

It has been possible to estimate age at death of 321 individuals. Of these skeletons only 9.3\% (30 individuals) were infants and young children up to the age of 5 years. The number of older children and adolescents (aged 6-19 years) was larger-78 skeletons corresponding to $24.3 \%$. The remaining 213 skeletons $(66.4 \%)$ were of adult individuals aged 20 years or more. The relatively low number of infants and young children probably reflects poor preservation of the more fragile skeletons of the young. The ratio of older children and adolescents to adults $(78 / 213=0.366)$ corresponds to what can be expected from medieval mortality profiles at other cemeteries in Europe.

It was possible to estimate the sex of 217 skeletons aged 15 years or more. There were 134 males and 83 females. There were 16 skeletons in this age group for which it was not possible to estimate sex reliably. This overrepresentation of males (134 males against 83 females) is in accordance with a hypothesis that a substantial number of the interred individuals were indeed friars.

The mortality profile was reconstructed using KaplanMeier survival analysis (Fig. 4). The mean age at death for the 217 individuals aged 15 or more was 35.6 years. There was a difference in mean age at death between males and females of 3.6 years. For the males the mean age at death was 36.9 years and for the females it was 33.4 years. Using

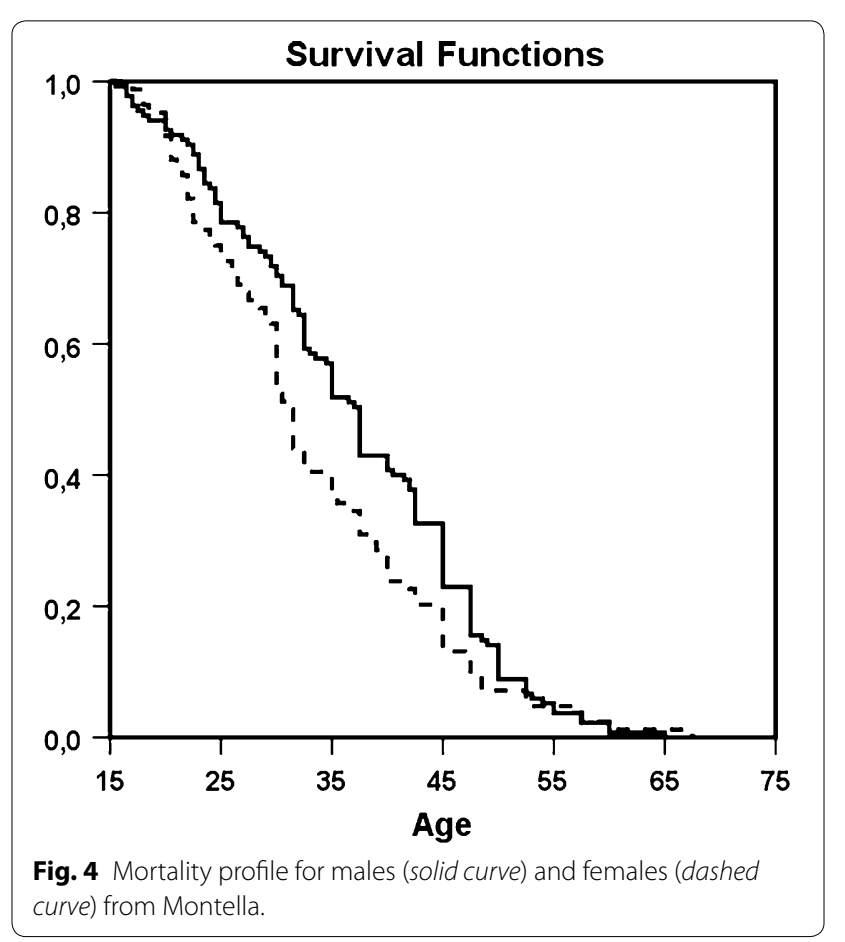


the Mantel-Cox log rank test this difference was found to be statistically significant: $\chi^{2}=3.85, \mathrm{df}=1, \mathrm{p}=0.0498$. In this context it is important to remember that the mortality profile-illustrating the distribution of age at death among the buried-in important aspects differs from the survival function-illustrating mortality as it would have been experienced in the once living population.

\section{Femoral length}

The burials were generally disturbed in a way so that later burials and building activity rendered it impossible to measure the length of the bodies in their graves as described by Boldsen [12]. So in order to get an estimate of the height of people in Montella in the Middle Ages it is necessary to rely on the length of the femur. In Table 1 male and female femoral lengths are compared to those from Central Italy based on data from Giannecchini and Moggi-Cecchi [36]. It appears that the Montella males had significantly shorter femora than men from the rest of Italy. If body proportions in the Montella samples correspond to body proportions in the rest of medieval central Italy, then the Montella men were on average some 6-7 cm shorter than their fellow Italians from the same historical period. Although height can be a result of many factors, including health and diet, the genetic factor has to be considered too.

\section{Skeletal trauma}

It was possible to find evidence for skeletal traumatic lesions in a total of 70 skeletons. Of these ten percent (7 individuals) had a traumatic skeletal lesion in one of the four body regions examined (head, arms, legs and torso). It appears that the legs were the least affected region of the body and the arms the most affected. Of

Table 1 Descriptive statistics for femoral length of the skeletons from Montella and samples of Middle Italian medieval skeletons (data from Giannecchini and MoggiCecchi, 2008)

\begin{tabular}{lrr}
\hline & Males & Females \\
\hline Montella & & \\
$N$ & 16.0 & 9.0 \\
Mean & 428.9 & 413.0 \\
SD & 30.2 & 15.3 \\
Middle Italy & & \\
N & 145.0 & 111.0 \\
Mean & 456.3 & 419.7 \\
SD & 37.5 & 19.1 \\
t-test & & \\
t-value & 2.82 & 1.02 \\
p-value & 0.005 & 0.31 \\
\hline
\end{tabular}

the seven individuals with traumatic skeletal lesions, four had lesions in only one region, two had lesions in two regions and one skeleton showed traumatic lesions in three regions of the body. This last individual was attacked and killed by numerous blows with a sharp instrument. The frequency of trauma was virtually the same for men and women $(\mathrm{p}=0.92)$ and individuals with and without traumatic skeletal lesions died at very similar ages $(p=0.27)$. The sample comes from a rather special cemetery: the individuals paid to be buried in the cloister walk of a friary, but they still had to be worthy of praise as devoted Catholics. It is therefore less likely they died as a consequence of violence or that they committed suicide. In this light the low level of skeletal trauma caused by violence is to be expected. The case of the USD 295 is an exception to the rule, as his unusual trauma proves.

\section{Joint degeneration}

In 48 skeletons at least one of the four major appendicular joints-shoulder, hip, knee and ankle-could be examined. Ten of these skeletons (21\%) showed such changes in at least one joint. The affected joint was most frequently the knee (in 13\% of the skeletons) and the least affected joint was the shoulder (4\%). It appears that men and women were equally prone to developing joint degeneration $(\mathrm{p}=0.44)$. Degenerative joint changes are age progressive. Once they have occurred they do not disappear again. Following this, it is not surprising that people who died with this condition were on average nearly 17 years older than those who died without them $(\mathrm{p}=0.00021)$.

\section{Leprosy and tuberculosis}

The sample of skeletons can be seen as originating from a mixture of two types of people, those who suffered from leprosy and those who did not. The mixture composition of a given sample is reflected both in the mean and the variance for the $\lambda$-statistic. Figure 5 illustrates the deviation from the optimum as a function of leprosy frequency $(\pi)$. The $\pi$-interval where the solid curve lies below the horizontal long-dashed line constitutes the confidence interval. Using this approach it can be estimated that the most likely frequency of leprosy in the Montella sample $(\hat{\pi})$ is $0.12(12 \%)$ corresponding to five out of the 44 individuals giving information about leprosy in the sample. The $95 \%$ confidence interval for this statistic is (3.9$21.2 \%$ ). This means that the sample with $95 \%$ probability contains between two and nine skeletons of people who suffered from leprosy. Both the mean $\lambda$-value and the variance for $\lambda$ indicate very similar frequencies 12.2 and $12.0 \%$, respectively. 


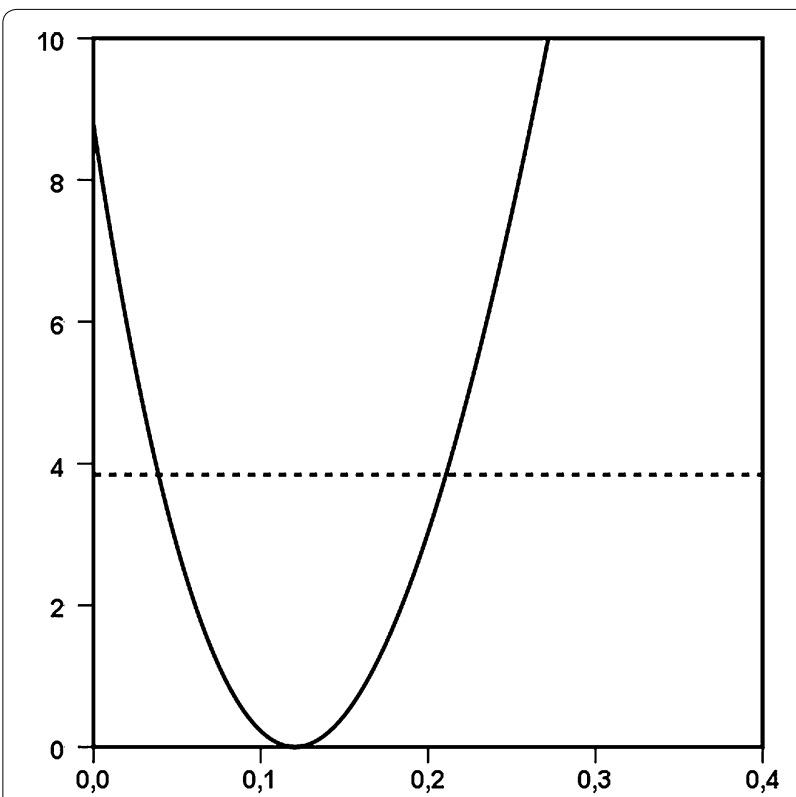

Fig. 5 The estimation curve for leprosy frequency among the Montella skeletons. The horizontal axis gives the leprosy frequency and the vertical axis the lack of fit to the most probable frequency. The interval where the parabola like curve is under the dotted line is to the $95 \%$ confidence interval for the prevalence estimate.

It is commonly assumed that leprosy is a disease that people died with but not a disease that they died from. In the sense that leprosy rarely was or is the proximal cause of death, this is probably true. However, it is unlikely that people with leprosy did not experience elevated risks of dying compared with those who avoided contracting the disease. So, it is of interest to analyse the distribution of age at death among people with and without leprosy. As demonstrated above, there is a difference in the distribution of age at death for men and women and as there is only one female skeleton with leprosy the survival analysis could only meaningfully be carried out for males. In a figure illustrating the mortality profiles (estimated through Kaplan-Meier analysis) for men with and men without leprosy (figure not shown), and using the Mantel-Cox log rank test this difference was found to be statistically significant: $\chi^{2}=4.53, \mathrm{df}=1, \mathrm{p}=0.033$. It appears that men with leprosy on average died at higher ages than men without leprosy did. The mean difference in age at death in the two diagnostic groups is approximately 9 years. In a large pre-antibiotic data set [37] the median age at debut with leprosy was between 35 and 40 years. The difference between the mean ages at death in the two diagnosis cohorts can easily be accounted for by the selection effect of a late age at debut with leprosy. On the other hand, given the magnitude of the age at death difference selective mortality for leprosy must have been very slight.
Although the leprosy frequency in the Montella sample did not reach the level commonly seen in Southern Scandinavia [38], leprosy was by no means an unknown disease in Southern Italy in the Middle Ages.

Tuberculosis was diagnosed with more than one characteristic lesion in nine skeletons out of 33, which is ca. $27 \%$. This frequency is in accord with findings from other European cemeteries, e.g. in Denmark: 22\% in Viborg Skt. Morten [39], 35\% out of 600 skeletons from Odense [40].

\section{Radiocarbon dating}

${ }^{14} \mathrm{C}$ ages of the 50 analyzed bone samples are shown in Table 2 and Fig. 6. Even though this is only ca. $16 \%$ of the individuals identified at the cemetery, the overall impression from Fig. 6 is that of a continuous use of the cemetery through the period from AD 1222-1524, known from the historical sources. The oldest dated individual was the female in grave USD-372 with a calibrated radiocarbon date of AD 1024-1206 (2 sigma range), which likely pre-dates the foundation of the friary in AD 1221-1222 according to the historical sources. The second-oldest individual, USD-230, exhibits an age which is consistent within the 2 sigma uncertainty range (AD 1050-1249) with an individual from the first generation of occupants of the friary. However, it is also possible that this individual pre-dated the foundation of the friary. Two individuals, USD-210 and USD-295, also died in the 13th Century, while the majority most likely lived and died in the 14th Century. Three individuals, USD260, USD-280 and USD-298 are from the 15th Century; while the youngest grave is that of USD-240 exhibiting a 2 sigma calibrated date range of AD 1430-1633. This shows the use of the friary potentially extended into the 16 th or 17 th centuries.

\section{Diet and stable isotopes}

The stable isotope data are listed in Table 3 and shown in Fig. 7. The data points towards a mixed agricultural and pastoral diet as highlighted by the average values obtained for the $\delta^{13} \mathrm{C}(-19.7 \pm 0.7) \%$ and the $\delta^{15} \mathrm{~N}$ $(7.1 \pm 1.1) \%$. A probable presence of C4 plant (millet) in the diet is recognizable for the sample USD459 T31 for which the $\delta^{13} \mathrm{C}$ is $-18.0 \%$, considering that the millet has been shown to be present in Italy by the Bronze Age [41].

The $\delta^{13} \mathrm{C}$ and $\delta^{15} \mathrm{~N}$ average and standard deviation for the two subsample concerning primary and secondary graves has been calculated. No differences are found for the two subsamples as it is clear from the isotopic results: (1) primary graves $(\mathrm{n}=41) \delta^{13} \mathrm{C}=-19.7 \%$ $( \pm 0.8), \delta^{15} \mathrm{~N}=6.9 \%$ o $( \pm 0.9)$; (2) secondary graves $(\mathrm{n}=7)$ $\delta^{13} \mathrm{C}=-19.4 \%$ o $( \pm 0.2), \delta^{15} \mathrm{~N}=8.3 \%$ о $( \pm 1.2)$. 
Table 2 Results of radiocarbon dating: lab. no. are radiocarbon laboratory codes

\begin{tabular}{|c|c|c|c|c|c|}
\hline USD-no. & Lab. no. & KLR-no. & ${ }^{14} \mathrm{C}$ age $(\mathrm{BP}) \pm 1 \sigma$ & Calibrated age (AD. 1 $\sigma$ ) & Calibrated age (AD. 2 $\sigma$ ) \\
\hline \multirow[t]{3}{*}{ USD-274 } & DSH614 & KLR-7106 & $709 \pm 39$ & 1,263-1,299 (60.4\%) & $1,224-1,235$ (1.9\%) \\
\hline & & & & $1,370-1,380(7.8 \%)$ & $1,241-1,315(75.6 \%)$ \\
\hline & & & & & $1,356-1,389(17.9)$ \\
\hline \multirow[t]{3}{*}{ USD-230 } & DSH615 & KLR-7107 & $864 \pm 26$ & $1,161-1,215$ & $1,050-1,084(9.4)$ \\
\hline & & & & & $1,125-1,136(1.6 \%)$ \\
\hline & & & & & $1,151-1,249(84.4 \%)$ \\
\hline \multirow[t]{2}{*}{ USD-229 } & DSH616 & KLR-7108 & $656 \pm 25$ & $1,287-1,306(31.0 \%)$ & $1,280-1,320(45.4 \%)$ \\
\hline & & & & $1,363-1,385$ (37.2\%) & $1,350-1,392(50.0 \%)$ \\
\hline \multirow[t]{2}{*}{ USD-262 } & DSH617 & KLR-7109 & $560 \pm 15$ & 1,329-1,341 (26.1\%) & $1,320-1,350(42.7 \%)$ \\
\hline & & & & $1,396-1,412(42.1 \%)$ & $1,391-1,418(52 ; 7 \%)$ \\
\hline \multirow[t]{2}{*}{ USD-217 } & DSH618 & KLR-7110 & $584 \pm 24$ & $1,318-1,353(49.1 \%)$ & $1,304-1,365$ (66.6\%) \\
\hline & & & & 1,390-1,404 (19.1\%) & $1,384-1,413(28.8 \%)$ \\
\hline \multirow[t]{3}{*}{ USD-235 } & DSH619 & KLR-7111 & $618 \pm 17$ & 1,302-1,321 (28.7\%) & $1,296-1,330(37.4 \%)$ \\
\hline & & & & $1,349-1,367$ (26.6\%) & 1,339-1,398 (58.0\%) \\
\hline & & & & 1,383-1,392 (12.9\%) & \\
\hline \multirow[t]{2}{*}{ USD-210 } & DSH62O & KLR-7112 & $781 \pm 23$ & $1,225-1,234(15.7 \%)$ & $1,219-1,275$ \\
\hline & & & & $1,243-1,268$ (52.5\%) & \\
\hline \multirow[t]{2}{*}{ USD-250 } & DSH621 & KLR-7113 & $550 \pm 29$ & $1,326-1,344$ (24.1\%) & 1,314-1,357 (39.6\%) \\
\hline & & & & $1,394-1,421(44.1 \%)$ & $1,387-1,432(55.8 \%)$ \\
\hline USD-260 & DSH622 & KLR-7114 & $517 \pm 15$ & $1,412-1,428$ & $1,405-1,435$ \\
\hline \multirow[t]{2}{*}{ USD-273 } & DSH623 & KLR-7115 & $573 \pm 38$ & $1,316-1,355(42.5 \%)$ & 1,299-1,370 (59.3\%) \\
\hline & & & & $1,389-1,413(25.7 \%)$ & $1,380-1,425$ (36.1\%) \\
\hline \multirow[t]{2}{*}{ USD-240 } & DSH624 & KLR-7116 & $403 \pm 40$ & $1,441-1,513(57.7 \%)$ & $1,430-1,526(68.1 \%)$ \\
\hline & & & & $1,601-1,617(10.5 \%)$ & $1,556-1,633(27.3 \%)$ \\
\hline \multirow[t]{2}{*}{ USD-255 } & DSH625 & KLR-7117 & $546 \pm 18$ & $1,331-1,339(10.5 \%)$ & $1,323-1,346(23.4 \%)$ \\
\hline & & & & $1,397-1,420(57.7 \%)$ & $1,392-1,427$ (72.0\%) \\
\hline \multirow[t]{2}{*}{ USD-265 } & DSH626 & KLR-7118 & $687 \pm 26$ & $1,276-1,299(55.1 \%)$ & $1,269-1,310(69.5 \%)$ \\
\hline & & & & $1,370-1,380(13.1 \%)$ & $1,360-1,387$ (25.9\%) \\
\hline \multirow[t]{2}{*}{ USD-270 } & DSH627 & KLR-7119 & $641 \pm 28$ & $1,292-1,315(27.6 \%)$ & $1,283-1,328(41.0 \%)$ \\
\hline & & & & $1,356-1,389(40.6 \%)$ & $1,342-1,395$ (54.4\%) \\
\hline \multirow[t]{2}{*}{ USD-280 } & DSH1016 & KLR-7121 & $504 \pm 36$ & $1,409-1,440$ & $1,324-1,345$ (7.3\%) \\
\hline & & & & & $1,393-1,450(88.1 \%)$ \\
\hline \multirow[t]{2}{*}{ USD-238 } & DSH1015 & KLR-7122 & $673 \pm 23$ & $1,282-1,300(44.2 \%)$ & $1,276-1,313(57.6 \%)$ \\
\hline & & & & $1,369-1,381$ (24.0\%) & $1,358-1,389(37.8 \%)$ \\
\hline \multirow[t]{2}{*}{ USD-291 } & DSH1014 & KLR-7123 & $577 \pm 22$ & $1,320-1,350$ (45.3\%) & $1,307-1,363(62.7 \%)$ \\
\hline & & & & $1,392-1,407$ (22.9\%) & $1,385-1,415(32.7 \%)$ \\
\hline USD-298 & DSH1013 & KLR-7178 & $435 \pm 23$ & $1,436-1,459$ & $1,426-1,481$ \\
\hline \multirow[t]{2}{*}{ USD-354 } & DSH1011 & KLR-7180 & $642 \pm 26$ & 1,293-1,312 (26.7\%) & $1,284-1,325(40.6 \%)$ \\
\hline & & & & $1,358-1,387(41.5 \%)$ & $1,344-1,395(54.8 \%)$ \\
\hline \multirow[t]{2}{*}{ USD-266 } & DSH739 & KLR-7120 & $639 \pm 33$ & $1,292-1,317(27.8 \%)$ & $1,283-1,330(40.9 \%)$ \\
\hline & & & & $1,354-1,389(40.4 \%)$ & $1,338-1,398(54.5 \%)$ \\
\hline \multirow[t]{2}{*}{ USD-350 } & DSH1118 & KLR-7179 & $813 \pm 25$ & $1,216-1,258$ & $1,170-1,173(0.8 \%)$ \\
\hline & & & & & $1,181-1,267$ (94.6\%) \\
\hline \multirow[t]{3}{*}{ USD-295 } & DSH1831 & KLR-7181 & $862 \pm 66$ & $1,050-1,083$ (13.9\%) & $1,034-1,265$ \\
\hline & & & & $1,127-1,136(3.4 \%)$ & \\
\hline & & & & $1,151-1,251$ (50.9\%) & \\
\hline \multirow[t]{2}{*}{ USD-410 } & DSH3737 & & $586 \pm 61$ & $1,305-1,364(47.8 \%)$ & $1,287-1,431$ \\
\hline & & & & $1,385-1,410(20.4 \%)$ & \\
\hline
\end{tabular}


Table 2 continued

\begin{tabular}{|c|c|c|c|c|c|}
\hline USD-no. & Lab. no. & KLR-no. & ${ }^{14} \mathrm{C}$ age $(\mathrm{BP}) \pm 1 \sigma$ & 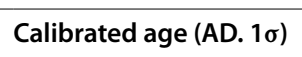 & Calibrated age (AD. 2 $\sigma$ ) \\
\hline \multirow[t]{3}{*}{ USD388 } & DSH3741 & & $612 \pm 41$ & $1,300-1,330(26.8 \%)$ & $1,290-1,409$ \\
\hline & & & & $1,339-1,370(27.1 \%)$ & \\
\hline & & & & $1,380-1,397$ (14.3\%) & \\
\hline USD-397 & DSH3729 & & $686 \pm 36$ & $1,263-1,320$ & $1,350-1,392$ \\
\hline \multirow[t]{2}{*}{ USD-425 } & DSH3727 & & $667 \pm 32$ & $1,282-1,306$ (36.9\%) & $1,275-1,321(50.9 \%)$ \\
\hline & & & & $1,363-1,385(31.3 \%)$ & $1,349-1,392(44.5 \%)$ \\
\hline \multirow[t]{2}{*}{ USD-429 } & DSH3742 & & $647 \pm 44$ & $1,286-1,318(30.8 \%)$ & $1,278-1,400$ \\
\hline & & & & $1,352-1,390(37.4 \%)$ & \\
\hline \multirow[t]{2}{*}{ USD-430 } & DSH3726 & & $552 \pm 28$ & $1,325-1,345(26.2 \%)$ & $1,314-1,357$ (41.2\%) \\
\hline & & & & $1,394-1,420(42.0 \%)$ & $1,388-1,430(54.2 \%)$ \\
\hline \multirow[t]{3}{*}{ USD-384 } & DSH3738 & & $614 \pm 24$ & $1,301-1,326(27.8 \%)$ & $1,296-1,400$ \\
\hline & & & & $1,344-1,368$ (27.0\%) & \\
\hline & & & & $1,382-1,394(13.4 \%)$ & \\
\hline \multirow[t]{2}{*}{ USD-386 } & DSH3739 & & $589 \pm 43$ & $1,310-1,361$ (49.7\%) & $1,295-1,418$ \\
\hline & & & & $1,387-1,406(18.5 \%)$ & \\
\hline \multirow[t]{2}{*}{ USD-387 } & DSH3723 & & $526 \pm 23$ & $1,405-1,430$ & $1,327-1,342(7.2 \%)$ \\
\hline & & & & & $1,395-1,438(88.2 \%)$ \\
\hline \multirow[t]{3}{*}{ USD-413 } & DSH3724 & & $410 \pm 38$ & $1,438-1,495$ (59.2\%) & $1,427-1,524(74.4 \%)$ \\
\hline & & & & $1,602-1,615(9.0 \%)$ & $1,559-1,563(0.5 \%)$ \\
\hline & & & & & $1,571-1,631(20.5 \%)$ \\
\hline USD-459 & DSH3725 & & $802 \pm 42$ & $1,208-1,270$ & $1,160-1,280$ \\
\hline USD-392 & DSH4407 & & $787 \pm 41$ & $1,220-1,270$ & $1,170-1,282$ \\
\hline \multirow[t]{2}{*}{ USD-399 } & DSH4408 & & $694 \pm 34$ & $1,272-1,300(54.3 \%)$ & $1,261-1,316(69.2 \%)$ \\
\hline & & & & 1,369-1,381 (13.9\%) & $1,355-1,390(26.2 \%)$ \\
\hline \multirow[t]{2}{*}{ USD-420 } & DSH4113 & & $654 \pm 29$ & $1,286-1,310(31.5 \%)$ & $1,279-1,324(45.0 \%)$ \\
\hline & & & & $1,360-1,387$ (36.7\%) & $1,346-1,394(50.4 \%)$ \\
\hline USD-438 & DSH4111 & & $747 \pm 30$ & $1,254-1,284$ & $1,222-1,288$ \\
\hline \multirow{3}{*}{ USD-380 } & DSH4112 & & $609 \pm 31$ & $1,302-1,329(27.6 \%)$ & $1,295-1,405$ \\
\hline & & & & $1,340-1,367(27.2 \%)$ & \\
\hline & & & & $1,383-1,396(13.4 \%)$ & \\
\hline \multirow[t]{2}{*}{ USD-377 } & DSH5235 & & $1,061 \pm 36$ & $905-916(8.3 \%)$ & $894-930$ (18.9\%) \\
\hline & & & & $967-1,020$ (59.9\%) & $937-1,025$ (76.5\%) \\
\hline \multirow[t]{3}{*}{ USD-407 } & DSH4010 & & $617 \pm 25$ & $1,300-1,325$ (27.7\%) & $1,295-1,399$ \\
\hline & & & & $1,345-1,369(26.8 \%)$ & \\
\hline & & & & $1,381-1,394$ (13.7\%) & \\
\hline \multirow[t]{2}{*}{ USD-451 } & DSH3740 & & $670 \pm 29$ & $1,281-1,305$ (38.8\%) & $1,275-1,319(53.3 \%)$ \\
\hline & & & & $1,364-1,384(29.4 \%)$ & $1,352-1,391$ (42.1\%) \\
\hline \multirow[t]{3}{*}{ USD-409 } & DSH5230 & & $856 \pm 30$ & $1,160-1,220$ & $1,050-1,083$ (7.9\%) \\
\hline & & & & & $1,126-1,135$ (1.2\%) \\
\hline & & & & & $1,151-1,258(86.3 \%)$ \\
\hline USD-444 & DSH5231 & & $826 \pm 35$ & $1,189-1,256$ & $1,155-1,273$ \\
\hline \multirow[t]{2}{*}{ USD-408 } & DSH5232 & & $731 \pm 38$ & $1,255-1,293$ & $1,220-1,301$ (91.2\%) \\
\hline & & & & & 1,368-1,382 (4.2\%) \\
\hline \multirow[t]{2}{*}{ USD-445 } & DSH3796 & & $554 \pm 33$ & $1,323-1,347$ (29.7\%) & $1,307-1,363(45.7 \%)$ \\
\hline & & & & $1,393-1,420(38.5 \%)$ & $1,385-1,434(49.7 \%)$ \\
\hline \multirow[t]{2}{*}{ USD-374 } & DSH5234 & & $861 \pm 41$ & $1,055-1,077$ (9.6\%) & $1,044-1,101$ (18.2\%) \\
\hline & & & & $1,153-1,224(58.6 \%)$ & $1,118-1,260$ (77.2\%) \\
\hline \multirow[t]{2}{*}{ USD-440 } & DSH5260 & & $590 \pm 27$ & $1,315-1,356(52.2 \%)$ & $1,299-1,370(68.6 \%)$ \\
\hline & & & & $1,389-1,402(16.0 \%)$ & $1,381-1,413(26.8 \%)$ \\
\hline
\end{tabular}


Table 2 continued

\begin{tabular}{|c|c|c|c|c|c|}
\hline USD-no. & Lab. no. & KLR-no. & ${ }^{14} \mathrm{C}$ age $(\mathrm{BP}) \pm 1 \sigma$ & Calibrated age (AD. 1\%) & Calibrated age (AD. $2 \sigma)$ \\
\hline \multirow[t]{3}{*}{ USD-449 } & DSH4557 & & $769 \pm 74$ & $1,183-1,290$ & $1,045-1,095$ (5.6\%) \\
\hline & & & & & $1,120-1,319(83.7 \%)$ \\
\hline & & & & & $1,351-1,391(6.1 \%)$ \\
\hline \multirow[t]{2}{*}{ USD-372F } & DSH5229 & & $925 \pm 44$ & $1,041-1,109(42.6 \%)$ & $1,024-1,206$ \\
\hline & & & & $1,116-1,157(25.6 \%)$ & \\
\hline \multirow[t]{2}{*}{ USD-372 M } & DSH4009 & & $732 \pm 34$ & $1,259-1,289$ & 1,221-1,299 (93.3\%) \\
\hline & & & & & $1,370-1,380(2.1 \%)$ \\
\hline
\end{tabular}

USD-numbers are excavation numbers, KLR-numbers are chemistry laboratory numbers. ${ }^{14} \mathrm{C}$ age is the radiocarbon age expressed in years Before Present (BP). Calibrated age intervals at $68 \%(1 \sigma)$ and $95 \%(2 \sigma)$ confidence level are reported with the corresponding relative probabilities in $\%$.

It is clear that none of the individuals were consuming marine protein, as all the $\delta^{13} \mathrm{C}$ are below $-18.0 \%$ VPDB and the $\delta^{15} \mathrm{~N}$ values are lower than would be expected for a marine based diet. This is not surprising considering the location is far from the sea.

It can also be ascertained from the $\delta^{15} \mathrm{~N}$ values, which range from 5.3 to $10.1 \%$, that the diet did not include freshwater fish. This is perhaps more surprising as there is a creek less than 100 meters from the convent. Without isotopic measurements for fish/ shellfish in lakes/rivers near Montella this is, however, harder to interpret. The absence of freshwater fish in the diet is fortuitous as it could otherwise give rise to a reservoir effect as has been reported in several places (see e.g. [42]). The radiocarbon dates can therefore in all likelihood be trusted for all of the dated individuals.

\section{Bone chemistry}

The results of the analyses by ICP-MS and CV-AAS are listed in Additional file 1: Table S4. Limits of quantization, LOQ, are calculated based on quality control runs performed over an at least 4 months period of regular use of the ICP-MS and the CV-AAS.

Tissue related differences in the abundances were seen for several of the elements. Zinc, $\mathrm{Pb}$ and $\mathrm{Mg}$ were more abundant in dentine than in bone; whereas $\mathrm{Hg}$ was more abundant in bone. There were no statistically significant differences between element concentrations or elemental ratios among the three different types of teeth (incisor, canine and wisdom tooth). In bone samples, it appears that $\mathrm{Ba}$ was more abundant in trabecular bone than in the two other types of bone sample. Lead was less abundant in compact bone than in the two other types of bone. More detailed interpretations follow below.

\section{Provenance}

Bones in the human body undergo re-modelling via the formation of osteons [43-47]. After adolescence the remodelling process continues throughout the remainder of life. The average turnover time is different for different tissue types. The cortical bone tissue generally exhibits an average turnover rate of ca. $2.5 \%$ per year and trabecular bone tissue has a faster turnover rate of ca. $10 \%$ per year $[44,48]$. There is one exception, namely pars petrosa which contains the organs of the inner ear. This bone is fixated (hence the name) at around the age of 2 years. Teeth also undergo very little re-modelling once formed, and the root of the first incisor $(+1)$ reflects the chemistry around the age of $9-10$, the canine $(+3)$ the age of $11-15$, and the third molar $(+8) 18-20$ years of age [49].

Provenance, i.e. the geographical site of residence, can be revealed individually or by a cross plot of the elemental ratios $\mathrm{Sr} / \mathrm{Ca}$ and $\mathrm{Ba} / \mathrm{Ca}[18,50]$. Like the $\mathrm{Sr}$-isotope ratios (see e.g. Price et al. [51]) the elemental ratios $\mathrm{Sr} /$ $\mathrm{Ca}$ and $\mathrm{Ba} / \mathrm{Ca}$ are less controlled by metabolic processes and more by the trace elemental contents of water and food, the latter mainly locally grown vegetables which are also strongly dependent on the $\mathrm{Sr}$ and $\mathrm{Ba}$ content of the surface waters available. In an individual residing at the same geographical location throughout life it is therefore to be expected that all the bones exhibit more or less similar $\mathrm{Sr} / \mathrm{Ca}$ - and $\mathrm{Ba} / \mathrm{Ca}$-ratios in the various bone elements, with the caveat that changes in metabolism may possibly introduce minor changes in the $\mathrm{Sr}$ and Ba uptake with age.

The elemental ratios $\mathrm{Sr} / \mathrm{Ca}$ and $\mathrm{Ba} / \mathrm{Ca}$ of the first incisor and the canine teeth, which reflect the provenance in childhood from 9 through 15 years of age, are shown in Fig. 8; the same data from the compact tissue and the trabecular tissue are shown in Figs. 9 and 10. Three groupings are indicated with circles on Fig. 8, the centre cluster is identified as Montella, because this cluster holds the largest number of data points of trabecular bone tissue (see Fig. 10). The trabecular bone tissue has the highest turnover rate of the investigated tissues and is therefore the tissue which reflects the latest times, i.e. closest to death, in the life of an individual. The other two clusters, termed "Site X" and "Site Y", are interpreted as originating from two other separate geographical locations. 


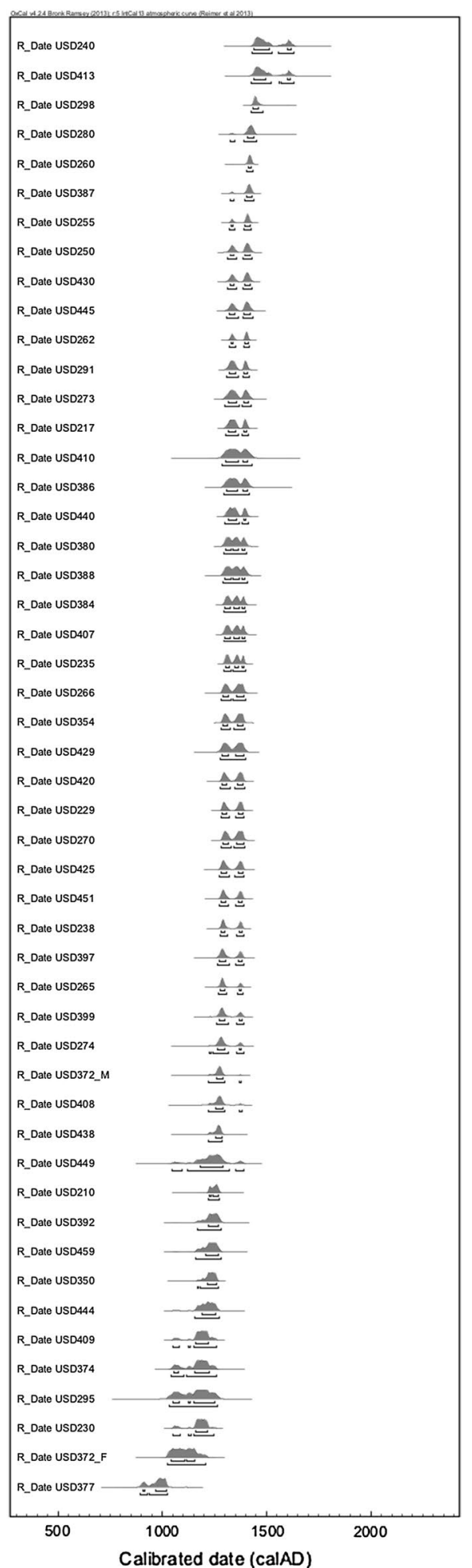

Fig. 6 Multiplot of the ${ }^{14} \mathrm{C}$ ages of all analyzed samples, calibrated by OxCal v4.2.3 program [28] and the IntCal13 calibration curve [29].
Based on the $\mathrm{Sr} / \mathrm{Ca}$ and $\mathrm{Ba} / \mathrm{Ca}$ provenance indicator of the teeth, our interpretation is that the individuals USD217, -240, -250, -260, -262, -283, -295, -219T3x, -219T3y, $-229,-273$, and -410 were all raised at "Site X". Examples of the provenance data for single individuals are shown in Figs. 11, 12, where it can be observed how the single individuals migrated through their lives. One individual, USD-230, was born and raised at location termed "Site Y", which is remote from Montella and "Site X", but USD230 lived a good part of his life and eventually died in Montella. This individual is radiocarbon dated to a two sigma range of AD 1050-1249, the second-earliest of all the radiocarbon dated individuals. This early date is consistent with the first generation of the founders of the convent-perhaps one of St. Francis's fellow travellers from Assisi. The rest of the individuals have $\mathrm{Sr} / \mathrm{Ca}$ and $\mathrm{Ba} / \mathrm{Ca}$ ratios consistent with a hypothesis that they were born, raised, lived and died in Montella.

\section{Mercury}

In many individuals the $\mathrm{Hg}$ concentration appears to have risen with age-it is lowest in pars petrosa, higher in compact bone and highest in trabecular bone. This could be due to an accumulative effect. Alternatively, the $\mathrm{Hg}$ concentration in the trabecular tissue could be interpreted to reflect the sum of the $\mathrm{Hg}$ in the bone tissue and the $\mathrm{Hg}$ originally present in the soft tissue, e.g. bone marrow, which is now decomposed and which will have left any $\mathrm{Hg}$ adhered to the surface of the lamellae of the trabecular bone. It has not been possible to mechanically decontaminate the trabecular bone tissue in the same thorough way it was done with the compact bone tissue samples.

Mercury was used for medical treatments already in the early medieval times $[19,52-54]$, but it got more and more popular during the late medieval times as a cure against syphilis. Mercury poisoning almost never leads to pathological bone lesions [55] and the use of $\mathrm{Hg}$ cannot therefore be diagnosed by looking at the bones. Normal non-exposed Hg-levels in compact bone tissue from medieval Denmark were reported by Rasmussen et al. [19] to be in the range $10-100 \mathrm{ng} \mathrm{g}^{-1}$; levels higher than these could indicate a treatment with an $\mathrm{Hg}$-containing medicine at some point in the life of the individual.

All the individuals analysed in this study exhibit belowthreshold Hg-values $\left(<100 \mathrm{ng} \mathrm{g}^{-1}\right)$ in the compact bone tissue samples. The $\mathrm{Hg}$ concentration in trabecular tissue is generally higher than in compact tissue [50], and the slightly higher values for $\mathrm{Hg}$ concentrations in the trabecular tissue for the three individuals USD-252.2, USD-253 
Table 3 Results of stable isotope measurements on the bone collagen

\begin{tabular}{|c|c|c|c|c|c|c|c|}
\hline USD & Tomb & Burial seq & $\delta^{13} \mathrm{C}$ & $\delta^{15} \mathrm{~N}$ & $\% \mathrm{C}$ & $\% \mathrm{~N}$ & $\mathrm{C} / \mathrm{N}$ \\
\hline 388 & Т.21 & 1 & -19.2 & 7.3 & 43.6 & 15.7 & 3.2 \\
\hline 397 & Т.22 & 1 & -20.8 & 5.5 & 41.4 & 14.9 & 3.2 \\
\hline 413 & Т.29 & 1 & -20.2 & 5.8 & 41.8 & 15.1 & 3.2 \\
\hline 425 & Т.26 & 1 & -19.3 & 8.3 & 42.3 & 15.1 & 3.3 \\
\hline 430 & Т.30 & 1 & -20.9 & 5.4 & 42.5 & 15.3 & 3.2 \\
\hline 429 & Т.30 & 1 & -20.2 & 6.8 & 41.8 & 14.9 & 3.3 \\
\hline 459 & Т.31 & 1 & -18.0 & 7.5 & 41.8 & 15.0 & 3.3 \\
\hline 384 & & 1 & -20.3 & 6.1 & 42.4 & 15.2 & 3.3 \\
\hline 386 & & 1 & -19.1 & 5.3 & 36.9 & 13.3 & 3.2 \\
\hline 410 & & 1 & -20.5 & 5.5 & 40.3 & 14.5 & 3.2 \\
\hline 451 & & 1 & -20.7 & 4.5 & 42.1 & 15.1 & 3.3 \\
\hline 407 & Т.27 & 1 & -20.0 & 6.5 & 42.0 & 15.6 & 3.1 \\
\hline 445 & & 1 & -19.5 & 6.2 & 40.8 & 15.1 & 3.1 \\
\hline 450 & & 1 & -19.4 & 7.2 & 41.5 & 15.3 & 3.2 \\
\hline 420 & & 1 & -19.3 & 6.8 & 42.2 & 15.7 & 3.1 \\
\hline 392 & Т.26 & 1 & -20.1 & 6.3 & 41.8 & 15.2 & 3.2 \\
\hline 444 & & 1 & -19.8 & 8.6 & 43.0 & 18.8 & 2.7 \\
\hline 408 & Т.23 & 1 & -19.6 & 7.7 & - & - & - \\
\hline 382 & & 1 & -19.7 & 7.1 & 43.1 & 19.2 & 2.6 \\
\hline 399 & Т.27 & 2 & -19.1 & 7.6 & 40.9 & 15.1 & 3.2 \\
\hline 380 & & 2 & -19.3 & 6.6 & 33.5 & 12.4 & 3.2 \\
\hline 438 & & 2 & -19.2 & 9.5 & 42.5 & 15.8 & 3.1 \\
\hline 372 & Т.25 & 2 & -19.4 & 7.4 & 36.4 & 13.7 & 3.1 \\
\hline 372 & & 2 & -19.6 & 7.9 & 41.3 & 15.9 & 3.0 \\
\hline 400 & & 2 & -19.5 & 10.1 & 21.6 & 11.4 & 2.2 \\
\hline 440 & & 2 & -19.6 & 8.8 & 40.2 & 16.1 & 2.9 \\
\hline 274 & Т.14 & 1 & -19.4 & 7.5 & 44.6 & 19.0 & 2.7 \\
\hline 230 & T.4 & 1 & -19.6 & 6.7 & 44.1 & 18.3 & 2.8 \\
\hline 229 & T.3 & 1 & -19.4 & 6.8 & 45.0 & 18.4 & 2.9 \\
\hline 262 & Т.12 & 1 & -23.0 & 6.9 & 43.7 & 18.2 & 2.8 \\
\hline 217 & T.2 & 1 & -19.5 & 7.2 & 44.4 & 18.2 & 2.8 \\
\hline 235 & T.5 & 1 & -19.3 & 8.3 & 44.3 & 18.3 & 2.8 \\
\hline 210 & Т.1 & 1 & -19.1 & 7.8 & 44.4 & 18.7 & 2.8 \\
\hline 250 & T.7 & 1 & -19.6 & 7.4 & 61.9 & 23.6 & 3.1 \\
\hline 260 & Т.11 & 1 & -18.8 & 6.7 & 44.5 & 16.1 & 3.2 \\
\hline 273 & T.8 & 1 & -19.7 & 7.0 & 40.5 & 17.1 & 2.8 \\
\hline 240 & T.6 & 1 & -19.7 & 6.9 & 40.7 & 17.7 & 2.7 \\
\hline 255 & Т.10 & 1 & -19.2 & 7.1 & 38.8 & 16.8 & 2.7 \\
\hline 265 & Т.13 & 1 & -19.3 & 8.3 & 41.2 & 17.4 & 2.8 \\
\hline 270 & Т.9 & 1 & -19.3 & 6.8 & 43.3 & 18.4 & 2.7 \\
\hline 266 & Т.12 & 1 & -19.9 & 7.3 & 44.2 & 18.6 & 2.8 \\
\hline 280 & Т.15 & 1 & -19.3 & 7.3 & 44.4 & 18.7 & 2.8 \\
\hline 238 & & 1 & -19.5 & 6.2 & 44.3 & 19.0 & 2.7 \\
\hline 291 & & 1 & -19.3 & 6.6 & 44.2 & 18.9 & 2.7 \\
\hline 298 & Т.17 & 1 & -19.7 & 7.4 & 44.3 & 18.8 & 2.8 \\
\hline 350 & Т.18 & 1 & -21.0 & 6.8 & 43.5 & 20.7 & 2.5 \\
\hline 353 & Т.14 & 1 & -19.7 & 7.7 & 42.3 & 18.1 & 2.7 \\
\hline 295 & Т.20 & 1 & -19.5 & 7.6 & 43.7 & 18.7 & 2.7 \\
\hline
\end{tabular}

Typical analytical precision evaluated from repeated measurements of the same sample is $0.1 \%$ for $\delta^{13} \mathrm{C}$ and $0.2 \%$ for $\delta^{15} \mathrm{~N}$. Also listed are the total wt $\% \mathrm{C}$ and $\mathrm{N}$ and the C/N-ratio. USD-295 T.20, a male, was beheaded. USD-274 T.1 is a male buried with a ceramic bowl in his arms. 


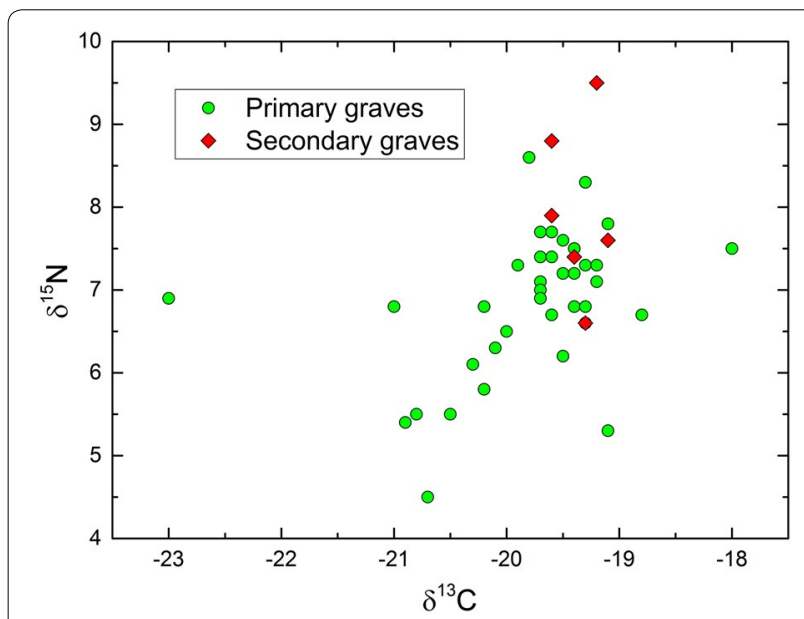

Fig. $7 \delta^{15} \mathrm{~N}$ as a function of $\delta^{13} \mathrm{C}$ in the collagen of the bones that have been radiocarbon dated. The green circles are skeletons in primary graves; red diamond shaped points are secondary. It is seen that none of the investigated individuals have been exposed to marine or freshwater fish in their diet.

and USD-265 are therefore also not indicative of the administration of $\mathrm{Hg}$-containing medicine. Certainly, none of the individuals diagnosed with leprosy in Montella have been treated with $\mathrm{Hg}$ (see Fig. 13), as was found to be the case for $79 \%$ of the leprosy cases at the Cistercian Monastery of Øm near Silkeborg in Denmark [19].

There are other possible sources of $\mathrm{Hg}$ in a medieval society, for instance the use of cinnabar $(\mathrm{HgS})$ as a colour pigment in manufacturing paintings, books and parchments, or the processes of gilding metallic objects. However, the data from the present study speaks in favour of the total absence of $\mathrm{Hg}$ in the monastic environment of Montella in terms of $\mathrm{Hg}$-containing medicine, widespread use of cinnabar $(\mathrm{HgS})$ in the scriptorium of the friary or other sources.

\section{Contamination and diagenesis}

Even though all the bone tissue samples except for the trabecular tissues have been thoroughly mechanically decontaminated there are still signs of diagenesis in some sample types for the elements $\mathrm{Al}, \mathrm{Fe}$ and $\mathrm{Mn}$, although the skeletons excavated in Montella are not nearly as contaminated as those from e.g. Schleswig in Germany or Svendborg in Denmark [18]. The likely explanation is that the $\mathrm{Al}$ originates from adhered soil $[50,56-58]$ and that Fe is deposited on the bones by the passing groundwater and precipitated by changes in $\mathrm{pH}[50,58-60]$. It is therefore likely that $\mathrm{Al}$ and $\mathrm{Fe}$ represent two different diagenetic processes. In Fig. 14 is shown $\mathrm{Al}$ versus Fe for all the samples in this study, and it is observed that a relatively

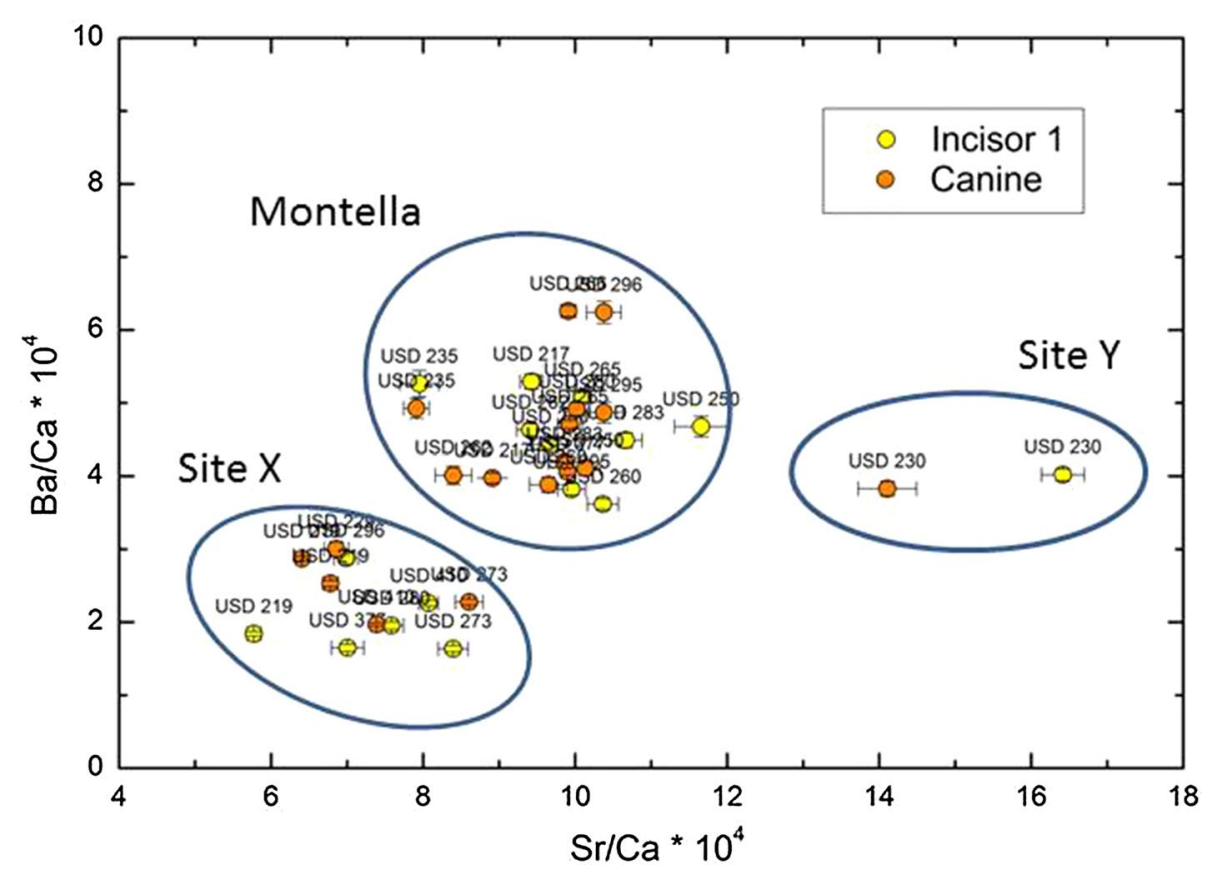

Fig. $8 \mathrm{Ba} / \mathrm{Ca}$ versus Sr/Ca for first incisor (yellow) and canine (orange). One sigma error bars indicating the uncertainty are shown. An interpretation of three different geographical areas of origin is indicated with ellipses. The centre ellipse is identified as Montella based on the fact that the similar data for trabecular bone tissue concentrates in this ellipse as can be seen in Fig. 10. The trabecular bone tissue is the tissue reflecting the diet and conditions latest in the life of an individual. 


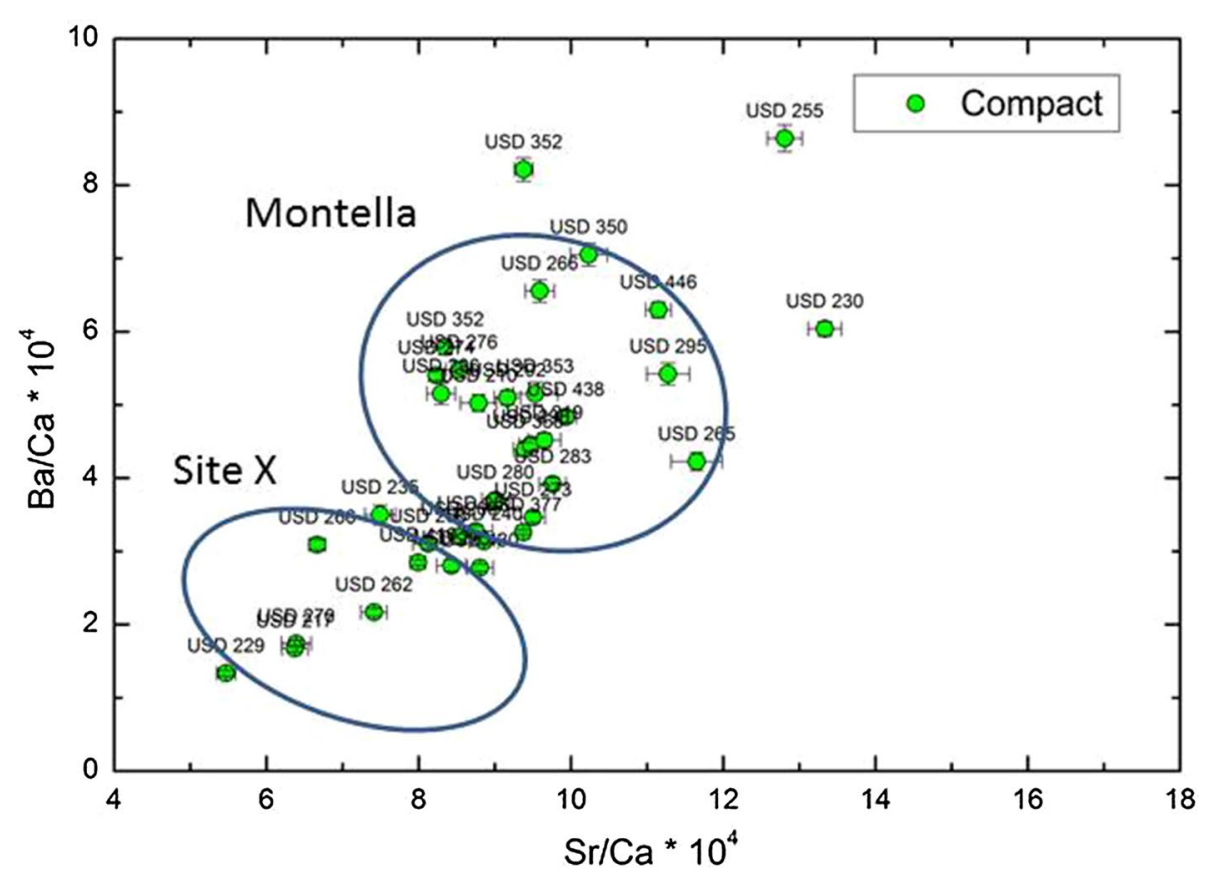

Fig. $9 \mathrm{Ba} / \mathrm{Ca}$ versus Sr/Ca for compact bone tissue samples. The same interpretation as in Fig. 8.

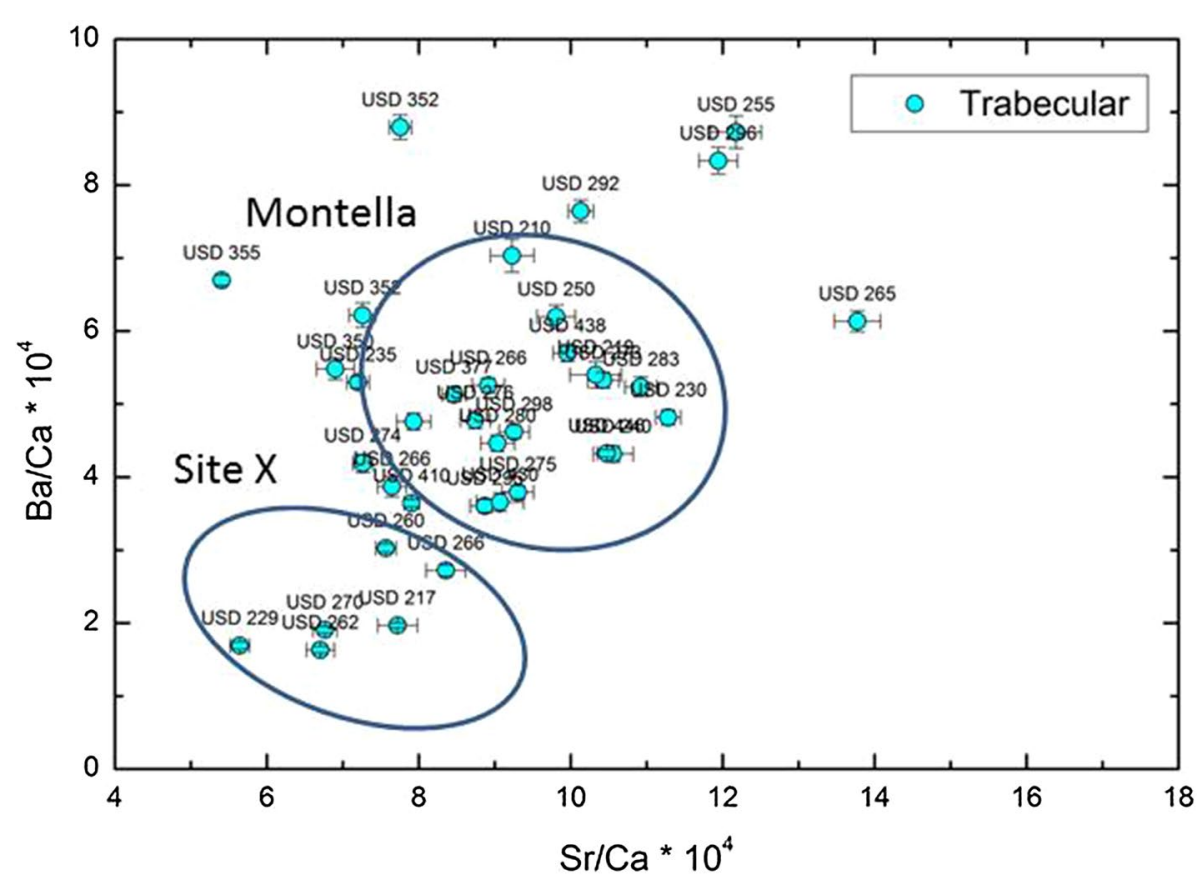

Fig. $10 \mathrm{Ba} / \mathrm{Ca}$ versus $\mathrm{Sr} / \mathrm{Ca}$ for trabecular bone tissue samples. The same interpretation as in Fig. 8.

good correlation exists between the logarithmic values of $\mathrm{Al}$ and $\mathrm{Fe}\left(\mathrm{r}^{2}=0.89\right.$ for the bone samples, excluding the teeth). This leads to the tentative conclusion that larger cumulative amounts of Fe-rich percolating ground water also leads to larger depositions of soil-not an unreasonable scenario.

It is evident that the material least exposed to groundwater contamination is the teeth and the compact bone 


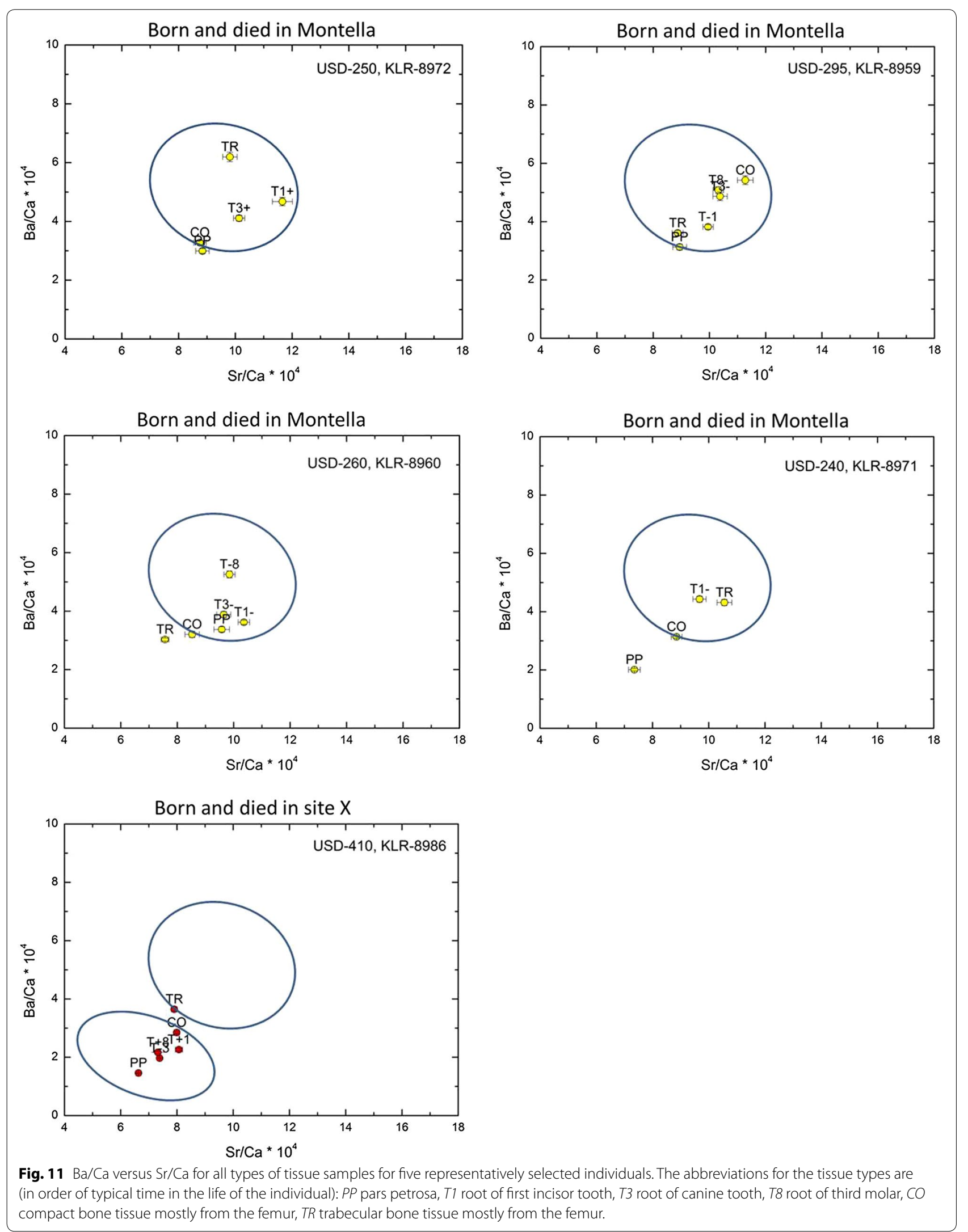




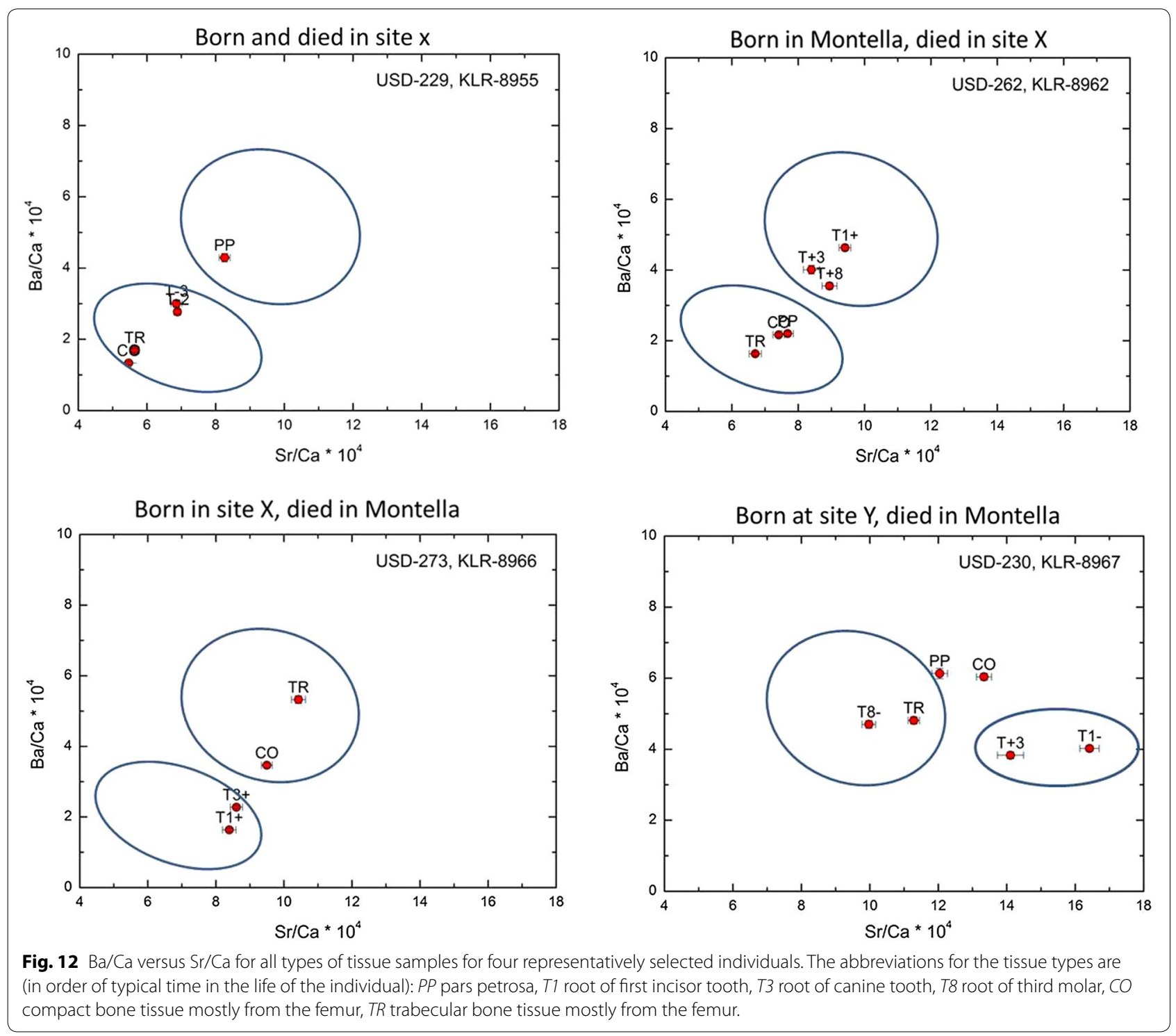

tissue, while the pars petrosa and the trabecular bone tissue, which is much harder to decontaminate and much more exposed to contamination by percolating ground water and invading soil particles, are more exposed to diagenesis.

The correlation between the concentrations of the two water soluble elements $\mathrm{Fe}$ and $\mathrm{Mn}$ is quite weak (see Fig. 15). In particular, there is no significant correlation between $\mathrm{Fe}$ and $\mathrm{Mn}$ for the teeth. For the bone samples there is a very weak correlation $\left(\mathrm{r}^{2}=0.36\right)$, as indicated by the linear fit to these tissue types in Fig. 15.

\section{Calcium content of compact femoral bone tissue}

The Ca concentration of compact femoral bone tissue is expected to be relatively constant throughout life. The skeletal organ may undergo mineral loss with increasing age for various reasons, but the $\mathrm{Ca}$ concentration in $\mathrm{mg} \mathrm{g}^{-1}$ in the remaining compact bone tissue is not expected to change. However, this does seem to be the case in Montella, particularly for the males as can be seen in Fig. 16, where the best fit indicates a decrease in $\mathrm{Ca}$ concentration of ca. $4 \%$ per decade. Such a decrease in Ca with age is apparently special for Montella as no significant decrease was observed in other places, e.g. at the Dominican cemetery in Schleswig, the cemetery at Ole Wormsgade in Horsens, the laymen cemetery at the Franciscan Friary in Svendborg, or in the rural parish cemetery at Tirup, Denmark (unpublished data). Except for the possible deficiency of vitamin D or the unlikely scenario of a ubiquitous Ca-depleted diet, we can offer no 


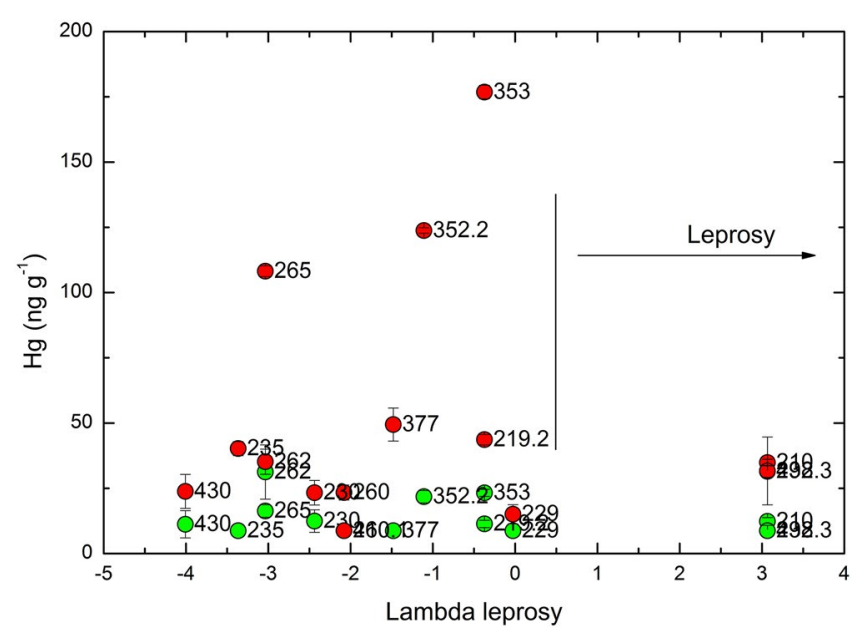

Fig. 13 The Hg concentration in femoral bone tissue as a function of the anthropological $\lambda$-score. Compact bone tissue samples are indicated with green points and trabecular tissue samples with red points. The one sigma uncertainties of the $\mathrm{Hg}$ determinations are indicated as bars. The range $\lambda$-values indicating the presence of leprosy is indicated by the line and arrow. The figure shows that none of the individuals suffering from leprosy were medicated with $\mathrm{Hg}$-containing medicine.

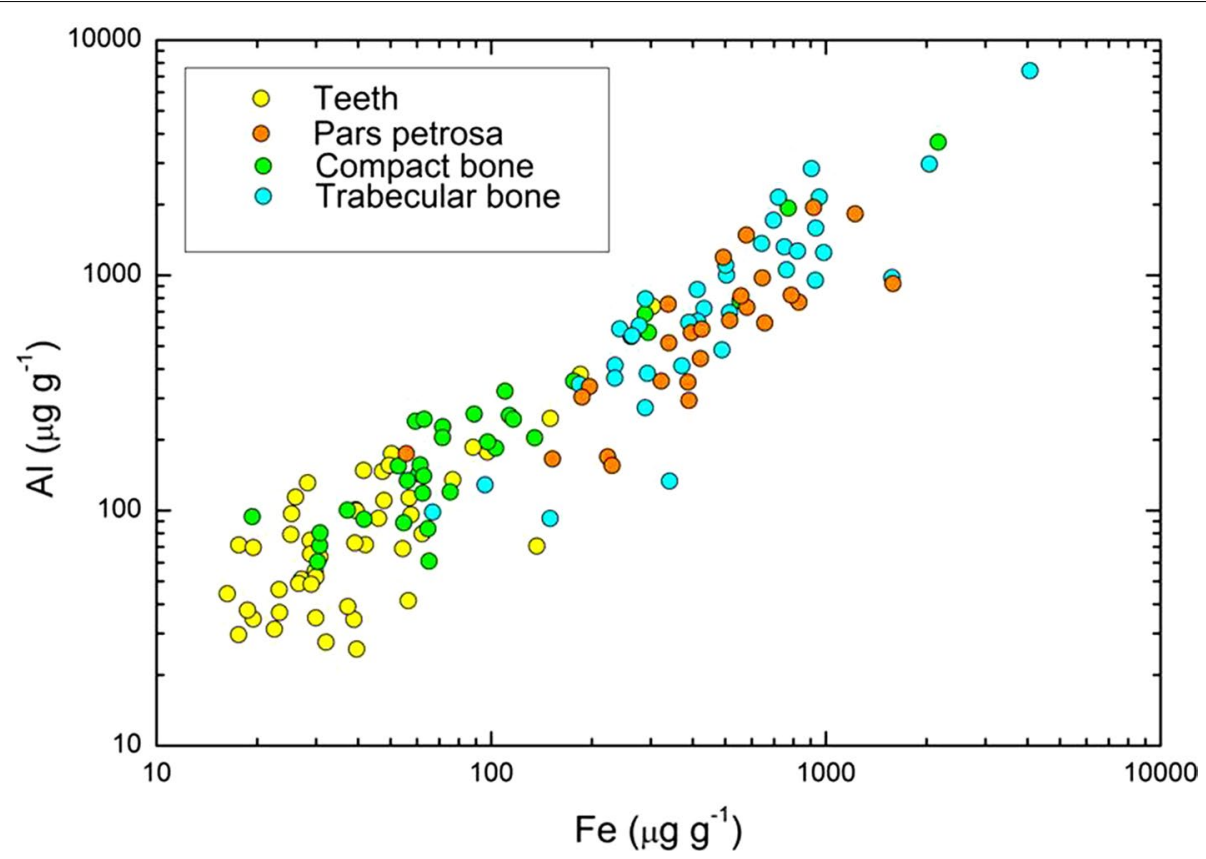

Fig. 14 Aluminium concentration versus Fe concentration for different tissue types. Teeth: yellow; pars petrosa: orange; Compact bone tissue samples: green; Trabecular bone tissue samples: turquoise. A strong correlation between Al and Fe is observed $\left(r^{2}=0.89\right)$.

explanation for this interesting feature of the individuals interred in Montella friary.

\section{Conclusions}

The men interred in the cloister walk in Montella were on average $6-7 \mathrm{~cm}$ shorter than was normal in central Italy in the Middle Ages. Nine skeletons out of 33
(27\%) showed signs of tuberculosis, while only five out of $44(11 \%)$ individuals likely suffered from leprosy. Treponema diseases were not observed. As commonly seen in medieval populations male mean age at death was higher than female age at death (36.8 versus 33.4 years for individuals surviving to 15 years). In Montella this difference is statistically significant $(\mathrm{p}=0.028)$. 


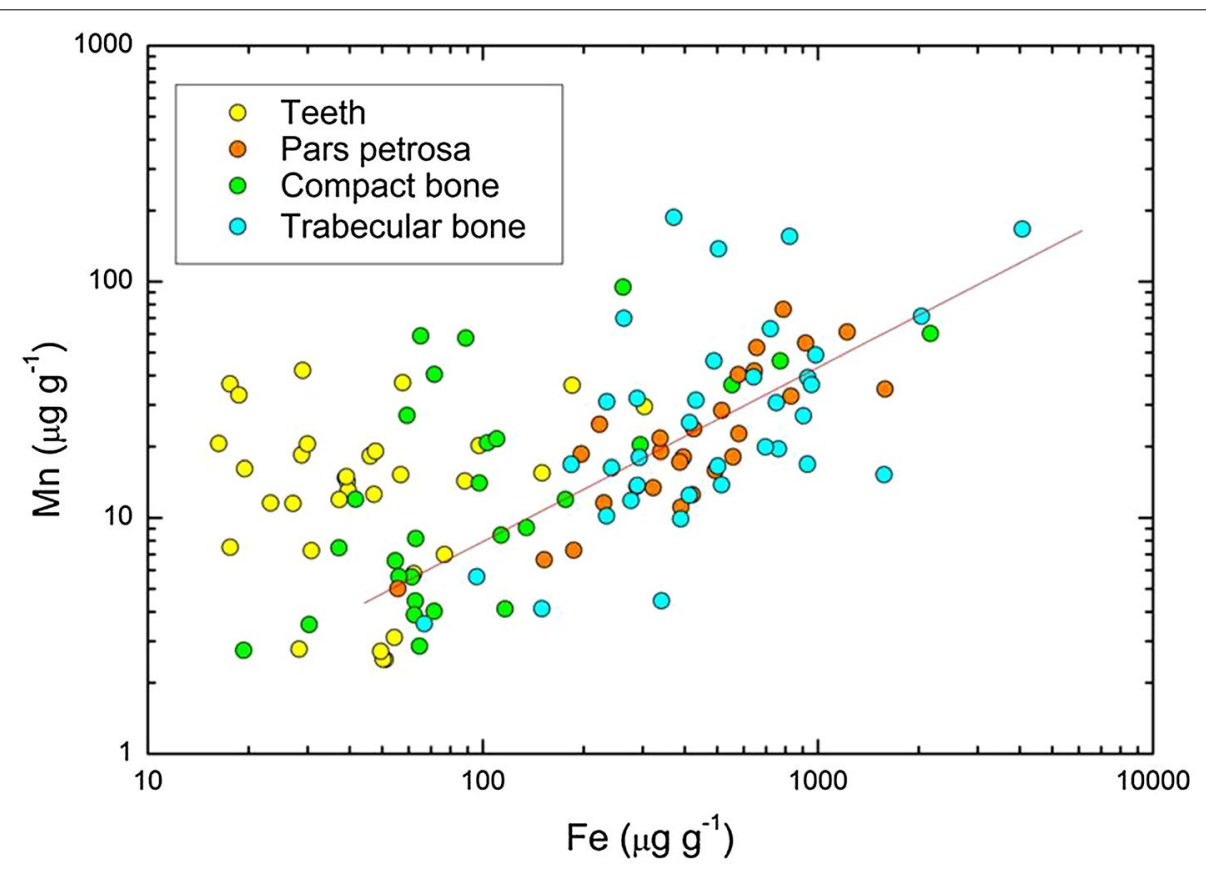

Fig. 15 Manganese concentration versus Fe concentration for different tissue types. Teeth: yellow; pars petrosa: orange; Compact bone tissue samples: green; Trabecular bone tissue samples: turquoise. A rather weak correlation between $\mathrm{Mn}$ and Fe is observed $\left(\mathrm{r}^{2}=0.36\right)$.

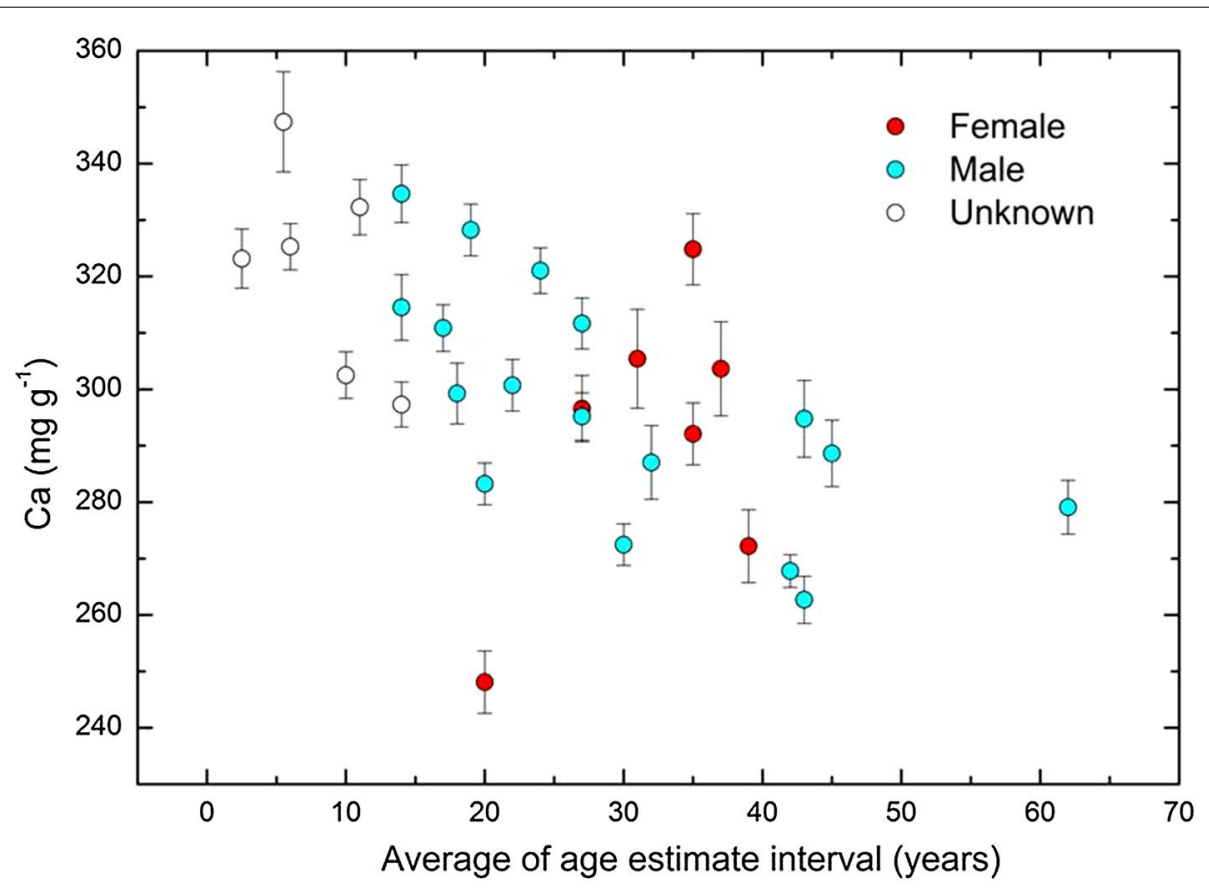

Fig. 16 The Ca concentration as a function of estimated age at time of death determined from anthropological observations. Females: red points; Males: turquoise; Undetermined sex: open points. A decline in Ca concentration with increasing age is observed.

Fifty individuals were radiocarbon dated. The distribution of the radiocarbon dates is consistent with a more or less continuous use of the cemetery from the foundation in AD 1221 and until 1524, in fine accordance with the historical sources. One individual most likely pre-dated the foundation of the friary in AD 1221-1222. The stable 
isotope measurements indicate the absence of both freshwater and marine reservoir effects, which leads to the conclusion that the radiocarbon dates can all be trusted to be accurate. The stable isotope measurements indicate a mixed agricultural/pastoral diet.

None of the investigated individuals had elevated Hgconcentrations, neither in the compact nor the trabecular tissue. There are therefore no indications of the use of $\mathrm{Hg}$ in the scriptorium as red ink (cinnabar) or as $\mathrm{Hg}$-containing medication in the friary or in the village.

A unique feature for the individuals interred in this cemetery is that there is observed a correlation between age at death of the individual and the Ca-concentration of the compact tissue of the femur. It is not known what caused this condition, which is not seen in other cemeteries.

Based on the measured $\mathrm{Sr} / \mathrm{Ca}$ and $\mathrm{Ba} / \mathrm{Ca}$ ratios it is suggested that all the investigated individuals except USD-230 lived a substantial part of their lives either in Montella or one other location ("Site X"). USD-230 is the most outstanding of the individuals in terms of mobility. Based on the $\mathrm{Sr} / \mathrm{Ca}$ and $\mathrm{Ba} / \mathrm{Ca}$ elemental ratios it seems likely that only the individual USD-230 was born at "Site Y", distinctly different in $\mathrm{Sr}$ and Ba inventory from Montella and "Site X". USD-230 was radiocarbon dated to a two sigma calibrated range of AD 1050-1249, which is second-earliest individual dated at the cemetery. The date is consistent with the first generation of the founders of the convent-perhaps it was a fellow traveller of St. Francis of Assisi, or perhaps it was a burial that pre-dated the foundation of the friary.

\section{Additional file}

Additional file 1: Table S4. Results of the ICP-MS and CV-AAS

measurements

\begin{abstract}
Authors' contributions
SS lead the excavations. MT, JLB and PT conducted the osteological investigations. KLR, LS and LN made the sample preparations and conducted the trace element determinations. FT, IP, PR and CL made the radiocarbon dating and measured the stable isotopes. All authors read and approved the final manuscript.
\end{abstract}

\footnotetext{
Author details

${ }^{1}$ Laboratory of Science and Techniques Applied to Archaeology, University Suor Orsola Benincasa, Via Santa Caterina da Siena, 37, 80135 Naples, Italy. 2 Institute of Forensic Medicine, ADBOU, Lucernemarken 20, 5260 Odense S, Denmark. ${ }^{3}$ Department of Physics, Chemistry and Pharmacy, University of Southern Denmark, Campusvej 55, 5230 Odense M, Denmark. ${ }^{4}$ Conventual Friars Minor, Pontifical Theological Faculty of St. Bonaventure, International College Seraphicum, Via del Serafico, 100142 Rome, Italy. ${ }^{5}$ Centre for Isotopic Research on Cultural and Environmental heritage (CIRCE), Viale Carlo III, 153, San Nicola La Strada, 81020 Caserta, Italy. ${ }^{6}$ INNOVA Scarl, Via Campi Flegrei 34, 80078 Pozzuoli, NA, Italy. ${ }^{7}$ Department of Mathematics and Physics, Second University of Naples, Viale Lincoln 5, 81100 Caserta, Italy. ${ }^{8}$ Department of Environmental Science and Technology, II University of Naples, Via Vivaldi, 43, 81100 Caserta, Italy.
}

\section{Acknowledgements}

The Friary of San Francesco a Folloni, Montella is thanked for permitting the excavations and the analyses. Agnello Stoia is thanked for continuing support from the start of this project. We are indebted to his never failing permissions, engagement and enthusiasm for the research conducted in the Montella Friary. Raffaele Coppola and Flavio Petroccione, Provincia di Avellino, are thanked for helping the project underway. Giovanni Coppola and Giancarlo Fatigati, University Suor Orsola Benincasa are thanked for continuous help and support during the project. Paolo D'Imporzano is thanked for helping with the literature studies.

\section{Compliance with ethical guidelines}

\section{Competing interests}

The authors declare that they have no competing interests.

Received: 8 January 2015 Accepted: 23 July 2015

Published online: 01 September 2015

\section{References}

1. Scandone F (1916) L'Alta Valle del Calore. II. Il feudo e il municipio di Montella dal dominio dei Normanni a quello della casa Aragona, Palermo

2. Wadding L (1931) Annales Minorum seu Trium Ordinum a S. Francisco institutorum, a cura di J. M. Fonseca, vol II (1221-1237), Firenze

3. Strazzullo F (2000) II Complesso Mounomontale di San Francesco a FolIoni in Montella. Biblioteca S. Francesco. pp 125

4. Torino M (2012) La vita e la morte a Montella (Avellino) tra il 1200 ed il 1400: primi risultati dello studio sui resti umani rinvenuti durante le campagne di scavo nel Convento di S. Francesco a Folloni in Montella. Archeologia. Studi e ricerche sul campo 2012, I, http://www.unisob.na.it/ ateneo/annali/2011-2012_10_Torino.pdf

5. Schiavone S (2013) Convento di San Francesco a Folloni. 2005-2013 (Montella -Av). In: Notizie scavi e lavori sul campo, Schede 2012-2013, a cura di Sergio Nepoti, Archeologia Medievale XL, pp 294-297

6. White T, Folkens $P$ (2005) The human bone manual. Elsevier Academic Press, Burlington/San Diego/London

7. Bass W (1995) Human osteology. A laboratory and field manual. Missouri Archaeological Society Special Publication no 2. Missouri Archaeological Society, Columbia, MO

8. Milner GR, Boldsen JL (2012) Humeral and femoral head diameters in recent white american skeletons. J Forensic Sci 57:35-40

9. Milner GR, Boldsen JL (2012) Transition analysis: a validation study with known-age modern american skeletons. Am J Phys Anth 148:98-110

10. Boldsen JL, Milner GR, Konigsberg LW, Wood JW (2002) Transition Analysis: a new method for estimating age from skeletons. In: Hoppa RD, Vaupel JW (eds) Paleodemography: age distributions from skeletal samples. Cambridge University Press, Cambridge, pp 73-106

11. Bocquet-Appel JP, Masset CL (1982) Farewell to paleodemography. J Human Evol 11:321-333

12. Boldsen JL (1984) A statistical evaluation of the basis for predicting stature from lengths of long bones in European population. Am J Phys Anth 65:305-311

13. Ortner DJ (2003) Identification of pathological conditions in human skeletal remains, 2nd edn. Academic Press, San Diego/London

14. Boldsen $J$ L (2007) Leprosy in Medieval Denmark—a comprehensive analysis. Thesis University of Southern Denmark

15. Boldsen UL (2001) An epidemiological approach to the paleopathological diagnosis of leprosy. Am J Phys Anthropol 115:380-387

16. Boldsen JL (2005) Testing conditional independence in diagnostic palaeoepidemiology. Am J Phys Anthro 128:586-592

17. Boldsen $J L$ (2008) Leprosy in the early medieval Lauchheim community. Am J Phys Anthropol 135:301-310

18. Skytte L, Rasmussen KL (2013) Sampling strategy and analysis of trace element concentrations by Inductively Coupled Plasma Mass Spectroscopy on medieval human bones-the concept of chemical life history. Rapid Commun Mass Spectrom 27:1591-1599

19. Rasmussen KL, Boldsen JL, Kristensen HK, Skytte L, Hansen KL, Mølholm L et al (2008) Mercury levels in Danish medieval human bones. J Archaeol Sci 35(8):2295-2306 
20. Longin $\mathrm{R}$ (1871) New method of collagen extraction for radiocarbon dating. Nature 230(5291):241-242

21. Stafford TW, Jull AJT, Brendell K, Duhamel RC, Donahue D (1987) Study of bone radiocarbon dating at the University of Arizona NSF Accelerator facility for radioisotope analysis. Radiocarbon 29(1):24-44

22. Brown TA, Nelson DE, Vogel JS, Southon JR (1988) Improved collagen extraction method by modified Longin method. Radiocarbon 30(2):171-177

23. Passariello I, Simone P, Tandoh J, Marzaioli F, Capano M, De Cesare N et al (2012) Characterization of different chemical procedures for ${ }^{14} \mathrm{C}$ dating of buried, cremated, and modern bone samples at CIRCE. Radiocarbon 54(3/4):867-877

24. Passariello I, Marzaioli F, Lubritto C, Rubino M, D'Onofrio A, De Cesare N et al (2007) Radiocarbon sample preparation at the CIRCE AMS Laboratory in Caserta Italy. Radiocarbon 49(2):225-232

25. Marzaioli F, Borriello G, Passariello I, Lubritto C, De Cesare N, D'Onofrio A et al (2008) Zinc reduction as an alternative method for AMS radiocarbon dating: process optimization at CIRCE. Radiocarbon 50(1):139-149

26. Terrasi F, De Cesare N, D'Onofrio A, Lubritto C, Marzaioli F, Passariello I et al (2008) High precision 14C AMS at CIRCE. Nucl Instrum Methods Phys Res B 266(10):2221-2224

27. Stuiver M, Polach H (1977) Discussion: reporting of 14C data. Radiocarbon 19(3):355-363

28. Bronk Ramsey C, Lee S (2013) Recent and planned developments of the program OxCal. Radiocarbon 55(2-3):720-730

29. Reimer PJ, Bard E, Bayliss A, Beck JW, Blackwell PG, Bronk Ramsey C et al (2013) IntCal13 and Marine13 radiocarbon Age calibration curves 0-50,000 years cal BP. Radiocarbon 55(4):1869-1887

30. Chisholm BS, Nelson DE, Schwarcz HP (1982) Stable-carbon isotope ratios as a measure of marine versus terrestrial protein in ancient diets. Science 216:1131-1132

31. Schoeninger MJ, DeNiro MJ (1984) Nitrogen and carbon isotopic composition of bone collagen from marine and terrestrial animals. Geochim et Cosmochim Acta 48:625-639

32. Schwarcz HP, White CD, Longstaffe FJ (2010) Stable and radiogenic isotopes in biological archaeology: some applications. In: West BJ, Bowen GJ, Dawson TE, Tu KP (eds) Isoscapes: understanding movement, pattern, and process on Earth through isotope mapping. Springer, Netherlands

33. DeNiro MJ (1985) Postmortem preservation and alteration of in vivo bone collagen isotope ratios in relation to palaeodietary reconstruction. Nature 317:806-809

34. Pate FD (1994) Bone chemistry and paleodiet. J Archaeol Method Theory 1:161-209

35. Van Klinken GJ (1999) Bone collagen quality indicators for palaeodietary and radiocarbon measurements. J Arch Sci 26:687-695

36. Giannecchini M, Moggi-Cecchi J (2008) Stature in archaeological samples from Central Italy: methodological issues and diachronic changes. Am J Phys Anth 135:284-292

37. Meima A, Irgens LM, van Oortmarssen GJ, Jan H, Richardus JH, Habbema JDF (2002) Disappearance of leprosy from Norway: an exploration of critical factors using an epidemiological modelling approach. Inter J Epidemiol 31:991-1000

38. Boldsen JL, Rasmussen KL, Riis T, Ditmar M, Weise S (2013) Schleswig: medieval leprosy on the boundary between Germany and Denmark. Anthropologisher Anzeiger 70:273-287

39. Tarp P (2011) Anthropological site report: Viborg Skt. Morten VSM 09.715, ADBOU 2011, http://adbou.dk/index.php?id=67

40. Pedersen PD (2014) En seriemorders bekendelser. En undersøgelse af prævalens og patologi af tuberkulose i Odense 1050-1800. Unpublished master thesis SDU

41. Tafuri MA, Craig OE, Canci A (2009) Stable isotope evidence for the consumption of millet in Bronze Age Italy. Am J Phys Anthropol 139:146-153

42. Philippsen B (2013) The freshwater effect in radiocarbon dating. Herit Sci $1: 24$

43. Parfitt AM (1976) The actions of parathyroid hormone on bone: relation to bone remodeling and turnover, calcium homeostasis, and metabolic bone disease, Part I of IV parts: mechanisms of calcium transfer between blood and bone and their cellular basis: morphological and kinetic approaches to bone turnover. Metabolism 25(7):809-844

44. Parfitt AM (2002) Misconceptions (2): turnover is always higher in cancellous than in cortical bone. Bone 30(6):807-809
45. Lee CA, Einhorn TA (2001) The bone organ system: form and function. In Marcus R, Feldman D, Kelsey T (eds) Osteoporosis, 2nd edn. Academic Press, San Diego, pp 3-20

46. Ruimerman R (2005) Modeling and remodeling in bone tissue. Thesis, Technische Universiteit Eindhoven

47. Hadjidakis DJ, Androulakis II (1092) Bone Remodeling. Ann NY Acad Sci 2006:385-396

48. Reference Man (1975) Reference man: anatomical, physiological and metabolic characteristics, ICRP. Publication 23, Elsevier, Amsterdam

49. Ubelaker DH (1978) Human skeletal remains: excavation, analysis interpretation. Aldine Publ. Co., Chicago

50. Rasmussen KL, Skytte L, Pilekær C, Lauritsen A, Boldsen JL, Leth PM et al (2013) Distribution of mercury and other trace elements in the bones of two human individuals from medieval Denmark. Heritage Sci 1:10

51. Price TD, Manzanilla L, Middleton WD (2000) Immigration and the ancient city of Teotihuacan in mexico: a study using strontium isotope ratios in human bone and teeth. J Archaeol Sci 27:903-913

52. Steinbock R (1976) Paleopathological diagnosis and interpretation. Bone diseases in ancient human populations. In: Charles C, Thomas (eds) Springfield, Illinois

53. Charlier P (2006) Qui a tué la Dame de Beauté ? Étude scientifique des restes d'Agnès Sorel (1422-1450). Histoire des Sciences Médicales 40:255-263

54. Fornaciari G, Marinozzi S, Gazzaniga V, Giuffra V, Picchi MS, Giusiani M et al (2011) The use of mercury against pediculosis in the Renaissance: the case of Ferdinand II of Aragon, King of Naples, 1467-96. Med Hist 55(1):109-115

55. Tucker F (2007) The osteological evidence for the mercury treatment of syphilis in 17th to 19th century London. Lond Archaeol 11(8):220-224

56. Trueman CNG, Behrensmeyer AK, Tuross N, Weiner S (2004) Mineralogical and compositional changes in bones exposed on soil surfaces in Amboseli National Park, Kenya: diagenetic mechanisms and the role of sediment pore fluids. J Arch Sci 31:721-739

57. Fernandes R, Hüls M, Nadeau M-J, Grootes PM, Garbe-Schönberg C-D, Hollund $\mathrm{HI}$ et al (2013) Assessing screening criteria for the radiocarbon dating of bone mineral. Nucl Instrum Methods Phys Res Sect B 294:226-232

58. Keeley HCM, Hudson GE, Evans J (1977) Trace element contents of human bones in various states of preservation. J Archaeol Sci 4:19-24

59. Lopez-Gonzalez F, Grandal-d'Anglade A, Vidal-Romani JR (2006) Deciphering bone depositional sequences in caves through the study of manganese coatings. J Archaeol Sci 33:707-717

60. Kuczomow A, Cukrowska E, Stachnuik A, Gaweda R, Mroczka R, Paszkowicz W et al (2010) Investigation of chemical changes in bone material from South Africa fossil hominid deposits. J Archaeol Sci 37:107-115

\section{Publish with ChemistryCentral and every scientist can read your work free of charge \\ "Open access provides opportunities to our colleagues in other parts of the globe, by allowing anyone to view the content free of charge."}

W. Jeffery Hurst, The Hershey Company.

- available free of charge to the entire scientific community

- peer reviewed and published immediately upon acceptance

- cited in PubMed and archived on PubMed Central

- yours - you keep the copyright

Submit your manuscript here:

http://www.chemistrycentral.com/manuscript/ 